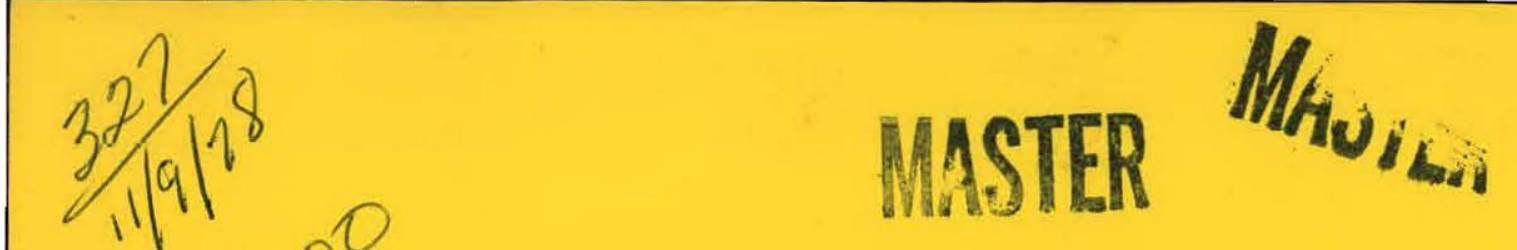

DOE/NASA CONTRACTOR REPORT

DOE/NASA CR-150730

\title{
DESIGN PACKAGE FOR INSTRUMENTATION OF THE DECADE 80 HOUSE IN TUCSON, ARIZONA
}

Prepared from documents furnished by

Copper Development Association, Inc.

405 Lexington Avenue

New York, New York 10017

Under Contract NAS8-32244 with

National Aeronautics and Space Administration

George C. Marshall Space Flight Center, Alabama 35812

For the U. S. Department of Energy

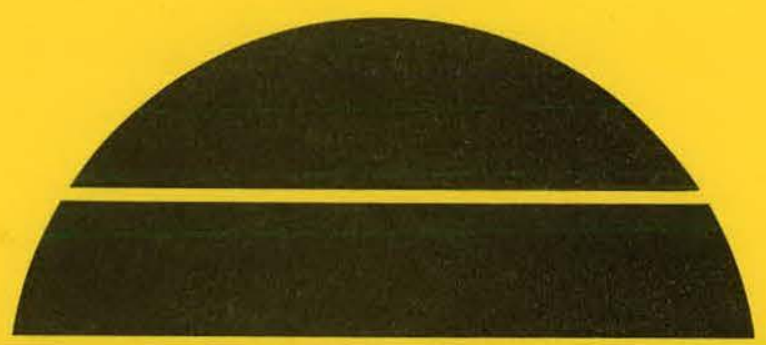

\section{U.S. Department of Energy}




\section{DISCLAIMER}

This report was prepared as an account of work sponsored by an agency of the United States Government. Neither the United States Government nor any agency Thereof, nor any of their employees, makes any warranty, express or implied, or assumes any legal liability or responsibility for the accuracy, completeness, or usefulness of any information, apparatus, product, or process disclosed, or represents that its use would not infringe privately owned rights. Reference herein to any specific commercial product, process, or service by trade name, trademark, manufacturer, or otherwise does not necessarily constitute or imply its endorsement, recommendation, or favoring by the United States Government or any agency thereof. The views and opinions of authors expressed herein do not necessarily state or reflect those of the United States Government or any agency thereof. 


\section{DISCLAIMER}

Portions of this document may be illegible in electronic image products. Images are produced from the best available original document. 
NOTICE

This report was prepared to document work sponsored by the United States Government. Nelther the United States nor 1ts agents the United States Department of Energy, the United States Nat1onal Aeronautics and Space Administration, nor any federal employees, nor any of their contractors, subcontractors or their employees, make any warranty, express or 1mplied, or assume any legal liability or responsibility for the accuracy, completeness, or usefulness of any information, apparatus, product or process disclosed, or represent that its use would not infinge privately owned rights. 


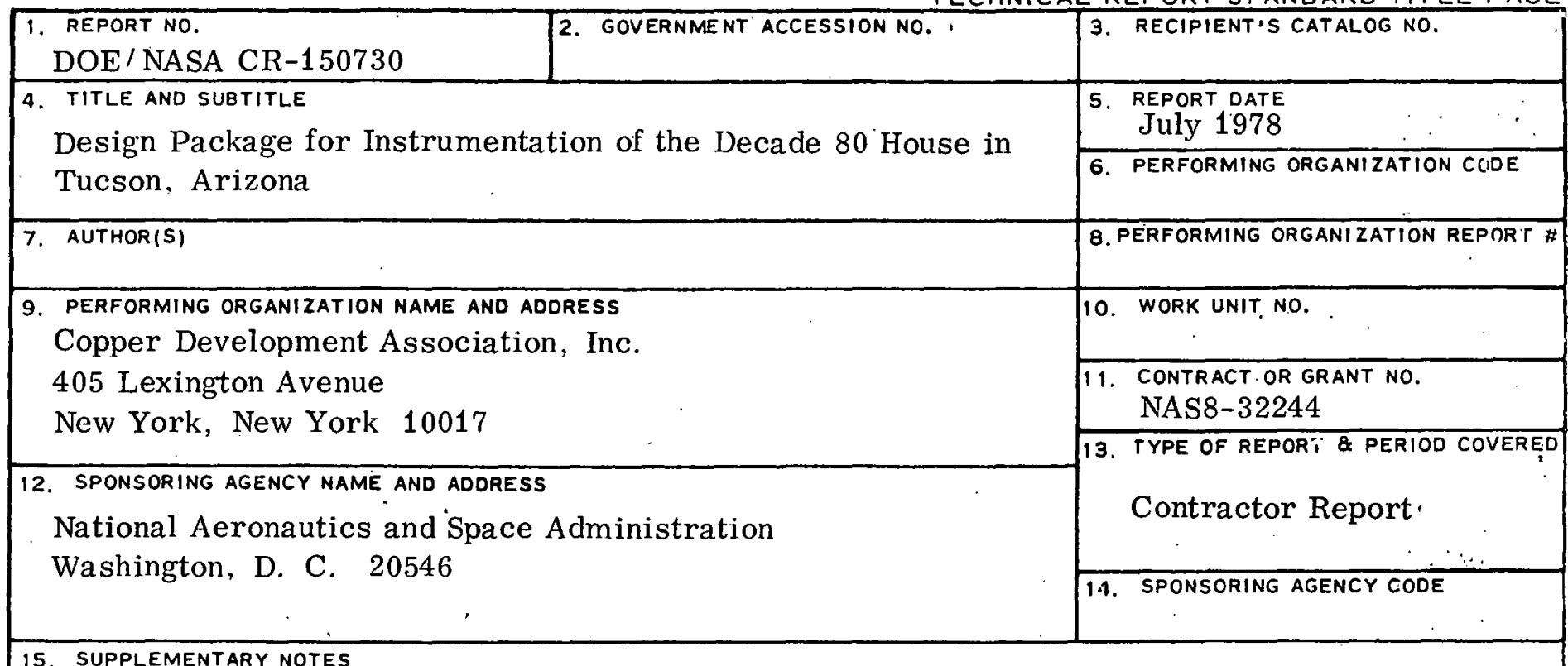

15. SUPPLEMENTARY NOTES

This work was done under the technical management of $\mathrm{Mr}$. Mitchell Cash, George C. Marshall Space Flight Center, Alabama.

16. ABSTRACT

This design package covers instrumentation and system design material submitted to the George C. Marshall Space Flight Center on January 15, 1977, for the first design review to be held January 28, 1977 in New York City.

MSFC has contracted with Copper Development Association, Inc., to instrument the Decade 80 solar house, located in Tucson, Arizona, for the purpose of gathering data to determine the solar heating and cooling system performance.

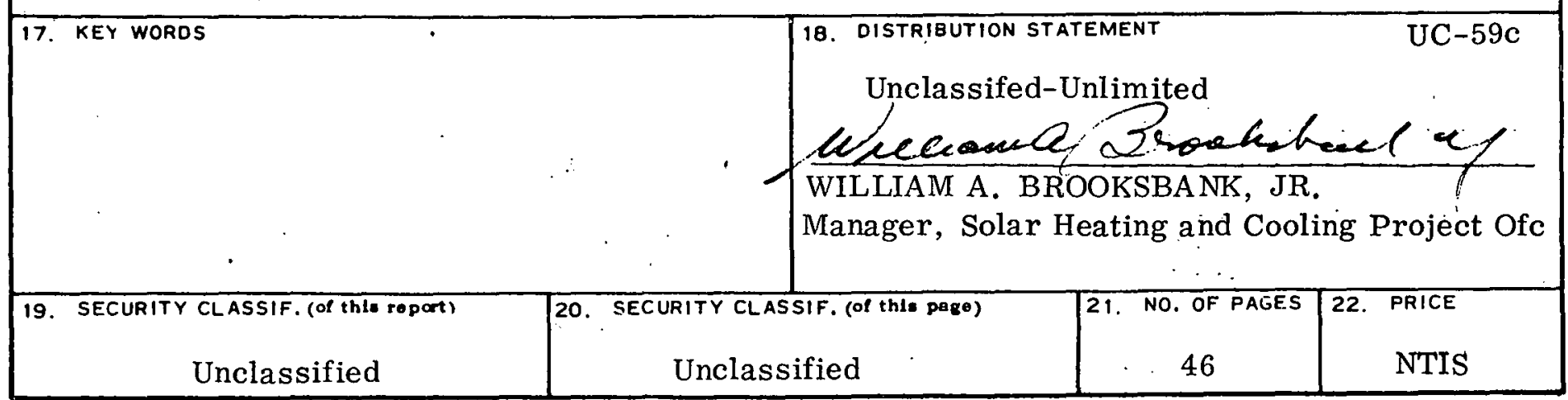


THIS PAGE

\section{WAS INTENTIONALLY \\ LEFT BLANK}


1.0 Site and System Description 1

2.0 Instrumentation Detinition 8

3.0 Installation Cost Proposal (Deleted) . 16 (For GSA Optional Form 60, see below)

4.0 Instrumentation Installation Completion Schedule

TABLE 1. PUMP SCHEDULE - 20

TABLE 2. INSTRUMENTATION PARTS SCHEDULE 20

FIGURE 1. VIEW OF DECADE 80 SOLAR HOUSE 22 SHOWING COLLECTOR ORIENTATION AND PYRANOMETER LOCATION

FIGURE 2. FLOOR PLAN SHOWING LOCATION OF SITE INSTRUMENTATION INSTRUMENT HARDWARE

APPENDIX A Decade 80 Solar House Brochure APPENDIX B Drawing $1^{*}$. Mechanical Plan. (Ducts)

APPENDIX C Drawing 2*. Heating/Cooling water Piping Diagram

APPENDIX D Drawings*. Heat Transfer Fluid Flows for Six Basic Operating Modes:

$$
\begin{array}{cl}
\text { Drawing } & \text { 3. Energy Collection } \\
& \text { 4. Heating from Storage } \\
\text { 5. Heating from Auxiliary } \\
\text { 6. Cooling from Storage } \\
\text { 7. Cooling from Auxiliary } \\
\text { 8. Domestic Water Heating }
\end{array}
$$

* Drawings only included in three copies. One (sepia) set of drawings is reproducible.

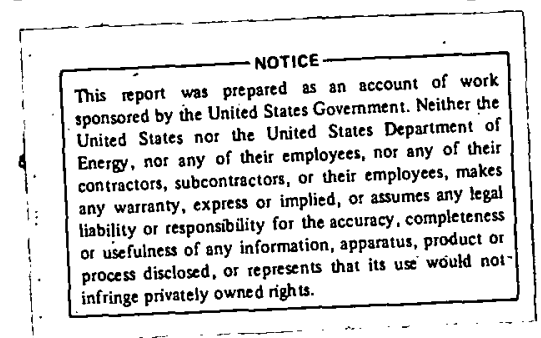


Proposed Installation Plan

for the Decade 80 Solar House

1.0 Site and System Description

1.1 site Contractor

Copper Development Association Inc.

405 Lexington Avenue

New York, New York 10017

(212) 953-7315

Field Office:

34 E. Madrid Place

Tucson, Arizona 85704

(602) 297-7020

1.2 Site Address

7779 N. Via Piccolina

Tucson, Arizona 85704

1.3 Purpose of Site

Single family residence.

1.4 Building Description

See 'brochure enclosed as Appendix A

1.5 System Descriptive Summary

1.5.1 Type:

Heating, absorption air-conditioning, and domestic water heating.

1.5.2 Collector area:

Gross area $=1923 \mathrm{sq} \mathrm{ft}$

Clear aperture $=1766 \mathrm{sq} \mathrm{ft}$

1.5.3 Collector description:

The collector is the Revere Copper and Brass Inc. Laminated Panel Collector, integral with the building roof. The collector is glazed with two panes of $1 / 8-$ inch glass preassembled in a frame. The glass is PPG Herculite $\mathrm{K}$ tempered glass as the outer pane, and annealed glass as the inner pane. 
Flow through the collector is $25 \mathrm{gpm}$; mass flow. is about $6.5 \mathrm{lb} / \mathrm{sq} \mathrm{ft}-\mathrm{hr}$. Flow is through a gridsinuous pattern of 22 parallel tubes. Each tube is folded back-and-forth in a sinuous path of about $200 \mathrm{ft}$ with a balancing cock in each flow path.

\subsubsection{Storage:}

The storage medium is tap water, treated with soda ash and sodium sulfite to inhibit rusting in the storage tank.

The storage container is a steel tank of 3000 gallon capacity. The tank contains about 2700 gallons of water, with the remaining space for expansion.

The tank is built of 1/4-inch steel plate formed into a cylinder; the ends of the tank are domed. The cylinder stands vertically, about $81 / 2 \mathrm{ft}$ in diameter. It was delivered to the site assembled.

The tank has an epoxy lining.

\subsubsection{Space heating method:}

The zoned heating system is a forced-air type, with two units, one serving the east zone and one serving the west zone. Air is heated by fan coils containing solar-heated water. Water is delivered to the fan coils at 5 to $11 \mathrm{gpm}$ directly from the storage tank.

In the event that there is not sufficient heat in the storage tank to satisfy the demand, heat is provided to the fan coils by an auxiliary natural-gas-fired boiler. 
1.5.6 Hot water subsystem:

Domestic water is heated through a heat exchanger and stored in a 66-gailon electric water heater, Rheem model 666H-660. The water heater electric elements are wired so they are in-circuit only when the main storage tank is below a preset temperature.

Hot water is circulated continuously to faucets throughout the house.

1.5.7 Energy transport:

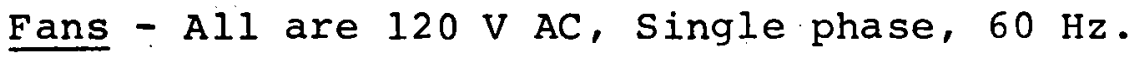

East zone uses one 3/4-HP blower.

West zone uses one 1/2-HP blower.

There is a duct booster-fan that controls air flow to the guest cabana. The fan is operated by the homeowner when he desires.

Ducts - All ducts are rigid fiberglass, in diameters from 6" to 16". The duct layout is shown in Drawing 1, enclosed as Appendix B.

Air flow through the east system is $1750 \mathrm{cfm}$; air flow through the west duct system is $1500 \mathrm{cfm}$.

Pumps - All pumps are $120 \mathrm{~V}$ AC, single phase, $60 \mathrm{~Hz}$, listed in Table 1, page 20.

Some modifications of the pumps will be required due to the increased head imposed by the instrumentation. Specifically, pump $\mathrm{P}-1$ will have to be replaced, the motor and impeller of pump $\mathrm{P}-2$ will be replaced and larger replacement impellers will be needed for $\mathrm{P}-3, \mathrm{P}-4, \mathrm{P}-5$ and $\mathrm{P}-6$. 
Pipe details - Drawing 2, The Heating-Cooling Water Piping Diagram (Appendix C) gives a detailed description of each pipe size and identifies all pumps, valves, heat exchangers, étc.

All tubes between the collector and $\mathrm{HE}-1$ and HE-2 are $1-1 / 2$ inch. All tubes into and out of the storage tank are $1-1 / 2$ inch.

Tubes to and from the Arkla generators and condensers, and tubes to each heating fan coil, are 1 inch:

All tubing is Type I copper. Fittings are copper, brass, or bronze. All joints are brazed with "Sil-Fos" silver-phosphorous-copper brazing alloys.

Fluid type - All fluids are tap water.

The collector water has about $35 \%$ propylene glycol antifreeze added to it. It is inhibited with phosphate.

The storage tank water has sodium nitrite and sodium sulfite added to it as rust inhibitors. About 10 lbs of each were used. The sodium sulfite is periodically replenished. This water circulates through the heating fan coils and the Arkla generators.

The cooling tower water has a polyphosphate stabilizer metered into it at about 1 to $10 \mathrm{ppm}$. An algaecide is added to the water once a month. The algaecide is consumed in a few days. The cooling tower 
water is bled off whenever the air conditioners are operating; bleed rate is $10.5 \mathrm{gal}$ per $\mathrm{hr}$ for each of the two Arkla air-conditioners.

1.5.8 Spáce cooling method:

Air-conditioners are three-ton Arkla lithium bromide absorption units, model XWF-501. Two are used; each cools one zone, or about half the living space. They are direct expansion types.

1.5.9 Auxiliary energy source:

Auxiliary energy for the heating and cooling subsystems is provided by a natural-gas-fired boiler: Teledyne Laars model HK--250--CNOlA. The labelled input is $250,000 \mathrm{Btu}$ per hr; output is $200,000 \mathrm{Btu}$ per hr.

The boiler has been modified by the removal of its two-stage gas valve, and replacement of it by a modulating valve and a partial bypass. Maximum output is now expected to be about 150,000 Btu per hr, with minimum continuous output about 50,000 Btu per hr. Auxiliary energy for domestic water heating is provided by the two electric heating elements within the domestic water storage tank. Each element is. 4500 watts, wired to operate one at a time. Auxiliary electric power is allowed to come on only when the main storage tank temperature drops below a preset temperature. 


\subsubsection{Operational control sequence:}

The operational control sequence is described in detail in Section 2.3 Operating and Control Modes

\subsubsection{Energy conversion efficiency:}

\section{Collection efficiency - The collector efficiency}

has been measured continuously for over a year.

Typical summertime day-long efficiency, integrated

over the total run-time of the collector (about 10:30

a.m. to $3: 30$ p.m.) is about 24 to $26 \%$. Typically

650,000 to 850,000 Btu are delivered to storage on

a normal clear day.

Typical wintertime day-long efficiency, integrated similarly, is 30 to $40 \%$. Up to $1,100,000$ Btu are collected on a clear December or January day. Recall also that the collector is sloped at $26^{\circ}$ above the horizontal, to emphasize collection of heat during the summer.

Storage losses - Heat delivered from storage to the HVAC system has been measured. On a typical day the air conditioning system draws from storage about 200,000 Btu. less than was delivered to storage by the collector.

About half the 200,000 Btu appears to have been used for domestic water heating. The other half is attributed to losses through the storage tank insulation, plumbing insulation, and to measurement error. Storage losses in the heating mode have not yet been analyzed. 
Domestic water heating losses - The domestic water storage tank/heater is wired to its own watt"hour meter. Domestic water heating energy consumption can therefore be measured by forcing the heater to remain in the electric heating mode. (It is set to the same temperature, $135 \mathrm{~F}$, that the solar water heating system.)

Typically the domestic water heating system will consume about $25 \mathrm{kwh}$ per day, with two occupants Iiving in the house. Of this amount, about 8 kwh per day is dissipated because of the continuous-circulation feature of the plumbing system. In addition, the circulator pump itself consumes about $2 \mathrm{Kwh}$ per day.

Additional insulation was added to the domestic water storage tank during the past summer. Before it was added energy consumption by the subsystem was about 6 to $10 \mathrm{Kwh}$ per day higher.

These measurements of electric energy consumption by the domestic water subsystem do not, of course; account for any losses that occur in the domestic water heat exchanger, $\mathrm{HE}-3$ or its associated plumbing. Arkla C.O.P. - Air-conditioner Coefficient of Performance has been measured approximately. Under steady-state operating conditions the COP of the Arklas has been measured at about $0.8 \pm 0.1$.

Day-long COP varied, of course, with the amount of cooling required throughout the day. During the summer it was about 0.8. Early and late in the cooling 
season it was lower, about 0.3 to 0.6 . During the summer both air-conditioners ran continuously from early morning till late night, typically 16 to 20 hours per day. Early and late in the cooling season the machines cycled rather frequently, lowering their effective coefficients of performance.

2.0 Instrumentation Definition

2.1 Instrumentation Locations

The Heating-coooling Water Piping Diagram (Appendix C) shows the proposed location of each sensor. Duct sizes are shown in Appendix B. The location of the two air duct flow rate sensors cannot be shown conveniently on the diagram. For the east zone, the sensor will be located in the vertical air return in the basement energy room. For the west zone, it will be located in a horizontal section of the air supply duct as it leaves the Arkla unit. In both cases flow straighteners will have to be used with the sensors.

The pyranometer will be mounted on a parapet wall near the ridge-iine as shown in Figure 1, page 22.

It is proposed to mount the outdoor dry bulb. temperature sensor a few yards west of the west wall of the house, behind a five foot high redwood fence. 
This listing appears in Table 2, page 20. It is keyed to the drawing in Appendix $C$ by the measurement numbers shown in the left-hand column of the table.

2.3 Operating and Control Modes

There are six basic operating modes in the Decade 80 Solar House energy system:

Energy collection

Space heating from storage

space heating from auxiliary energy

space cooling from storage

Space cooling from auxiliary energy

Domestic water heating

The heat transfer fluid flows for each of the six operating modes are shown schematically in the six drawings (Drawings 3 through 8) that make up Appendix D, and are described below.

2.3.1 Energy collection:

Energy collection is controlled by two differential thermostats (Rho sigma Model 12 modified units). When the collector surface temperature exceeds the temperature at the bottom of the storage tank pump P-l is turned on, circulating the water-antifreeze solution from the collector to heat exchangers $\mathrm{HE}-1$ and HE-2, and back to the collector.

A second differential thermostat turns pump P-2 on when the temperature of the antifreeze solution, as measured near the inlet of $\mathrm{HE}-1$, exceeds the temperature at the bottom of storage by about $3 \mathrm{~F}$. 
Pump P-2 circulates water from the bottom of the storage tank through $\mathrm{HE}-2$ and $\mathrm{HE}-1$, and back to the top of the storage tank.

All energy that is collected is delivered directly to the storage tank; there is no provision for bypass from the collector directly to the heating and cooling equipment.

2.3.2 Space heating from storage:

Upon demand for heat by either of the two room thermostats, pump $\mathrm{P}-3$ draws water from the solar storage tank. Warm water is provided to both fan coils, but admitted only to the one for which a demand was registered. Heat can be provided to either or both heating zones.

Water flow to each fan coil is set at $6 \mathrm{gpm}$. Each fan coil has a water bypass, so that its status (on or off) does not effect the rate of water flow to the other fan coil.

2.3.3 Space heating from auxiliary energy

Auxiliary heat, when required, is provided by a natural gas boiler. During the winter of 1975-1976 only $3 \%$ of the total heating Btu's were provided by the boiler. So far (January 1977) no auxiliary heat has been used during the current winter.

The heating system is controlled by a two-stage room thermostat in each zone. When the space temperature drops below the thermostat set-point, a stageone demand is created. Heat is provided to the space 
from the storage tank. If the storage tank is too cold to satisfy the demand for heat,..the space temperature will continue to drop.

When the space temperature drops $1.5 \mathrm{~F}$ below the set-point of the thermostat a stage-two demand is created. If this demand continues for seven minutes the auxiliary boiler will operate. The boiler will continue to operate, and provide heat to both fan coils, until the stage-two demand for heat is satisfied.

It has been found that the boiler might be needed during the coldest part of a morning, but as the day begins to warm there is sufficient heat still in storage to satisfy the smaller demand. Therefore the auxiliary heat source is load-dependent rather than supply temperature-dependent.

The seven minute time delay on the boiler was added to assure that the boiler does not operate unnecessarily. The occupant of the house might over adjust a thermostat upward or open a door on a cold, windy morning. This might create a sudden false stage two demand for heat that could actually be satisfied by stored heat.

For economy, water heated by the boiler should not be returned to the storage tank after passing through the fan coil. Therefore, whenever the gas 
boiler operates, proportioning valve $\mathrm{V}-2$ moves to the full bypass position. In this position water travels from pump $\mathrm{P}-3$ to the boiler, then to the heating coils, and finally through $\mathrm{V}-2$ and back to the pump.

\subsubsection{Space cooling. from storage:}

When the occupant of the house chooses to cool. the house he sets a summer/Winter switch to the summer position. This causes valves $\mathrm{V}-3$ and $\mathrm{V}-4$ to deliver hot water to the Arklas instead of the fan coils.

For proper operation the Arkla air conditioners require hot water between 190 and $210 \mathrm{~F}$. The storage tank may at times exceed $210 \mathrm{~F}$; therefore the stored hot water must be tempered somewhat. This is done by valve $\mathrm{V}-2$. If water from storage enters this valve too hot, cooler water returning from the airconditioners is mixed with the hot water, until the proper temperature is achieved.

The Arklas also require a means to dissipate the heat extracted from the house. This is the purpose of the cooling tower. The tower delivers water to the Arklas between 70 and $85 \mathrm{~F}$; the water is heated in the Arklas by 15 to 20 degrees and returned to the tower. At the tower some of the water is evaporated, causing the remaining water to be cooled. On a dry day the water may be cooled below $70 \mathrm{~F}$; this is not desirable. 
To maintain the cool water at no less than $70 \mathrm{~F}$ there is a proportioning valve, V-ll, at the cooling tower. If the tower chills the water excessively, unchilled water is delivered to the bottom of the tower, instead of the top, from which it returns, unchilled, to the Arklas. Valve V-Il mixes chilled and unchilled water to achieve the proper temperature.

Upon demand by either room thermostat for cooling, pumps $\mathrm{P}-3$ and $\mathrm{P}-6$ start, delivering hot water from storage and cool water from the cooling tower to the Arklas. Each Arkla has three-way valves and bypasses, so that cycling of one machine does not effect the water flow rates to the operating machine. The machines can operate alone or simultaneously.

As mentioned previously, the hot and cool water into the Arklas must be within certain temperature limits. If the cool water is too warm, or the hot water too cool, there is a danger of solidification, or crystallization, of the lithium bromide solution. To prevent the possibility of solidification there is a safety thermostat on each Arkla. This thermostat is a differential type; it allows air-conditioner operation only when the hot water is at least $110 \mathrm{~F}$ hotter than the cool water.

2.3.5 Space cooling from auxiliary energy:

The cooling system, like the heating system, is controlled by two two-stage thermostats, one in 
each of the two zones of the house. A first-stage demand for cooling from either thermostat will operate its air-conditioner, if certain conditions are met. The first condition, as described above, is that the hot water to the Arkla's generator must be at least $110 \mathrm{~F}$ hotter than the cool water to the machine's condenser. The second condition is that the hot water be at least $190 \mathrm{~F}$. If the water in the storage tank is below this temperature, thermostat $\mathrm{T}-4$, in the storage tank, signals valve $\mathrm{V}-2$ to close to the recirculate position. This prevents the water in the storage tank from circulating uselessly and losing heat through pipe insulation.

A second stage demand from either room thermostat indicates that, that zone has warmed more than 1.5 degrees above the thermostat set-point. If the storage tank is above $197 \mathrm{~F}$, the second stage demand has no effect. If the tank is below $197 \mathrm{~F}$ a second stage demand will first cause valve $V-2$ to close to the recirculate position. It then causes proportioning valve V-14 to respond to. its temperature sensor $\mathrm{T}-16$. As $\mathrm{V}-14$ begins to operate to admit water to the boiler, the opening of an end-switch on the valve allows the boiler circulating pump, $\mathrm{P}-10$, to start and sends a signal to the boiler gas valve. Flow through the boiler and P-lo trips a flow switch which then allows the boiler to begin operating. 
to begin operating.

There is a modulating gas valve in the boiler. The valve's regulator is set to raise the incoming water temperature by about 10 to 12 degrees. The boiler also has an over-temperature thermostat, set to $230 \mathrm{~F}$, which shuts off the boiler if the water becomes too hot.

Modulating valve V-I4 regulates the temperature of the water flowing from the boiler to the Arklas, holding the water to about $205 \mathrm{~F}$.

The boiler will come on and operate both Arklas whenever there is a second-stage cooling demand from either thermostat. There is no time delay in the cooling mode, as there is in the heating mode.

If the storage tank temperature is between 190 and $197 \mathrm{~F}$, the Arklas will operate from solar storage upon first-stage cooling demands and from the auxiliary boiler when either thermostat registers a second demand.

2.3.6 Domestic water heating:

The final. mode of operation is domestic water heating. Water is received from the city supply between 50 and $90 \mathrm{~F}$, and heated to 135. Domestic hot water is stored in a 66-gallon commercial electric water heater, whose electric heating elements are normally disabled. 
The hot water is circulated continuously through the house past all faucets. The water temperature is sensed by thermostat $T-7$ as the water returns to the base of the storage tank.

When the water temperature drops below $135 \mathrm{~F}$, T-7 causes pump P-4 to start. This pump draws hot water from the solar storage tank and sends it through the shell side of HE-3. After a 30-second delay (to allow the heat exchanger to warm up) pump P-5 starts sending domestic water from its storage tank to the tube side of HE-3. Both pumps run until $\mathrm{T}-7$ is satisfied. During the summer, with the storage tank normally above $180 \mathrm{~F}$, these pumps run for a one to two minute cycle every hour or two. During the winter the pumps run somewhat longer and more frequently. Thermostat T-5 measures the storage tank temperature. If the main tank is below about $140 \mathrm{~F}$ pumps P-4 and P-5 would run excessively, or continuously. Thus T-5 disables the pumps below its $140 \mathrm{~F}$ set-point, and instead puts the domestic water heater's electric heating elements into circuit.

2.4 Architectural Rendering

An aerial photograph of the Decade 80 Solar House appears as Figure 1, page 22, showing pyranometer location and collector orientation. There are no interfering surrounding structures.

3.0 Installation Cost Proposal. 
Cost information deleted.

4.0 Instrumentation Installation Completion Schedule

The installation schedule visualized is as

follows :

$\begin{array}{lc} & \text { Day } \\ \text { Receipt of instrumentation } & \text { zero } \\ \text { Begin installation } & 5 \\ \text { Complete installation } & 20 \\ \text { Installation checkout } & 24 \\ \text { System start-up and stabilization } & 23 \\ \text { Implementation plan complete } & 30\end{array}$

5.0 Additional Information

Junction Box modification - If it is feasible

we would like to have the NASA Junction Box built

so that the instrumentation sensor wires enter the bottom of the box, and the J-BOx/SDAS Interface

Cable connectors mounted on the top of the J-Box. Collector surface temperature measurement -

While we recognize that a measurement of collector surface temperature is not necessary for efficiency or heat balance calculations, we feel that such a measurement would be useful. Such a measurement would indicate the collector's freezing-temperature susceptability, and the temperature experienced by the collector/roof if the collector should experience "stall" conditions.

Natural gas flow - We find no suggestion for a transducer to indicate natural gas flow to the 
auxiliary boiler. The boiler has a pilot light which consumes about 1.5 to 2 cu ft per hr of gas; when the boiler ignites gas flow probably increases to more than $240 \mathrm{cu}$ ft per hr.

We recognize that gas flow transduction is difficult; Colorado State University is understood to have worked for several months on this problem. The auxiliary gas boiler at the Decade 80 House is, of course, served with a gas meter. Outdoor wet-bulb temperature measurement - While wet-bulb temperature measurement is not necessary for heat balance purposes, it is a useful measurement to indicate the efficiency of a cooling tower. Location of Site Instrumentation Interface Hardware - The mechanical room (basement) of the house can experience $110^{\circ}$ temperatures in the summer, even though all equipment is well insulated and the room is ventilated by a fan. Therefore a closet on the west end of the house, formerly used to store swimming pool equipment, has been chosen for the site data acquisition equipment, as indicated on the floor plan, Figure 2, page 23. Sensor wires will reach the equipment closet via a 6-inch plastic conduit from the main mechanical room and a 3-inch duct brought in from the west Arkla room.

The CDA computer equipment has been moved to this room and has been operating successfully there. 
During the winter the room temperature has quite stable at 70 to $80 \mathrm{~F}$, day and night. Power lines have been brought in to the room from the main breaker pane1: one line for the computer equipment and one for an air-conditioner that may be necessary in the summer.

The main telephone entrance to the house is through this closet. 
TABLE 1. PUMP SCHEDULE

\begin{tabular}{|c|c|c|c|c|c|c|c|c|}
\hline \multirow[b]{2}{*}{ Pump } & \multicolumn{2}{|c|}{ Current draw, A } & \multirow{2}{*}{$\begin{array}{l}\text { Manufacturer } \\
\text { and Model }\end{array}$} & \multirow[b]{2}{*}{ Size } & \multirow{2}{*}{$\begin{array}{l}\text { Flow, } \\
\text { gpm }\end{array}$} & \multirow{2}{*}{$\begin{array}{l}\text { Head, } \\
\mathrm{ft}\end{array}$} & \multirow[b]{2}{*}{ HP } & \multirow[b]{2}{*}{ RPM } \\
\hline & Label & Measured & & & & & & \\
\hline P-1 & 7.1 & 7.0 & B\&G 1522 & $11 / 2 A A B$ & 25 & 30 & $1 / 2$ & 1750 \\
\hline P.2 & 4.9 & 4.7 & " & $11 / 4 A A B$ & 25 & 15 & $1 / 4$ & $"$ \\
\hline P-3 & 12 & $10-10.5$ & “ & $11 / 4 A A B$ & 22 & 47 & 1 & 3450 \\
\hline P.4 & 4.9 & 4.3 & “ & $11 / 4 A A B$ & 25 & 12 & $1 / 4$ & 1750 \\
\hline P.5 & 4.9 & 4.6 & $"$ & $11 / 4 A A B$ & 25 & 23 & $1 / 4$ & $"$ \\
\hline P.6 & 12 & 12.7 & “ & $11 / 4 A A B$ & $20-30$ & 48 & 1 & 3450 \\
\hline P.9 & 0.85 & $?$ & Grundfos & UP-25-42SF & & & $1 / 20$ & 2620 \\
\hline P.10 & 4.9 & 4.9 & B\&G 1522 & $1 \mathrm{AA}$ & 22 & 15 & $1 / 4$ & 1750 \\
\hline
\end{tabular}

TABLE 2. INSTRUMENTATION PARTS SCHEDULE - PRIMARY MEASUREMENTS

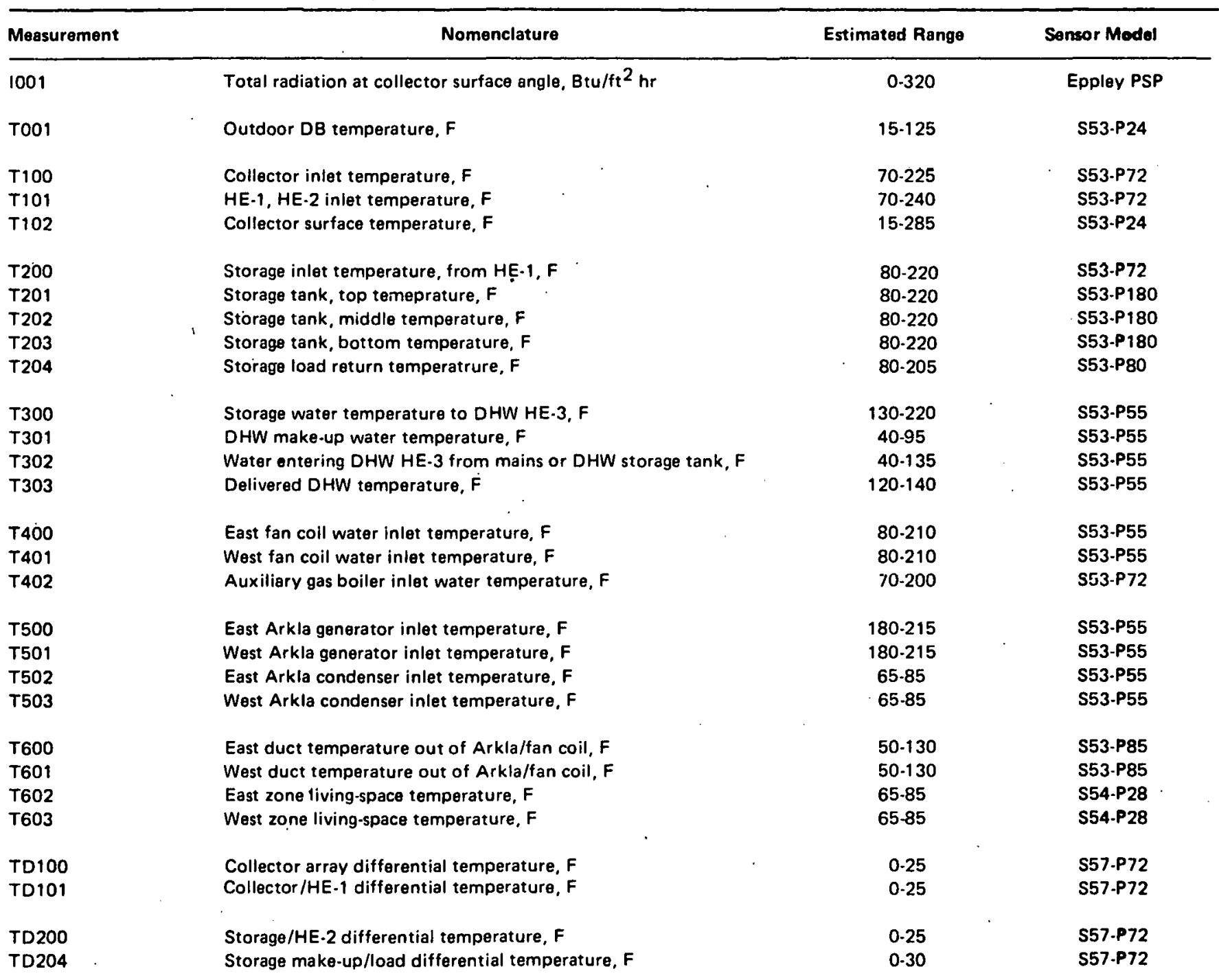


TABLE 2. INSTRUMENTATION PARTS SCHEDULE - PRIMARY MEASUREMENTS (Continued)

\begin{tabular}{|c|c|c|c|}
\hline Measurement & Nomenclature & Estimated Range & Sensor Model \\
\hline TD300 & DWH HE-3 storage-side differential temperature, F & 0.50 & S57-P55 \\
\hline TD301 & DHW load differential temperature, $F$ & $40-100$ & S57-P55 \\
\hline TD302 & DHW HE-3 differential temperature, $F$ & $0-40$ & S57-P55 \\
\hline TD400 & East fan coil water differential temperature, $F$ & $0-30$ & S57-P55 \\
\hline TD401 & West fan coil water differential temperature, F & $0-30$ & S57-P55 \\
\hline TD402 & Auxiliary boiler water differential temperature, $F$ & $0-25$ & S57-P72 \\
\hline TD500 & East generator water differential temperature, $\mathrm{F}$ & $0-15$ & S57-P55 \\
\hline TD501 & West generator water differential temperature, F & $0-15$ & S57-P55 \\
\hline TD502 & East condenser water differential temperature, $F$ & $0-20$ & S57-P55 \\
\hline TD503 & West condenser water differential temperature, F & $0-20$ & S57-P55 \\
\hline TD600 & East duct $\mathrm{H} / \mathrm{C}$ air differential temperature, $\mathrm{F}$ & $0-60$ & S57-P85 \\
\hline TD601 & West duct $\mathrm{H} / \mathrm{C}$ air differential temperature, $\mathrm{F}$ & $0-60$ & S57-P85 \\
\hline W100 & Collector flow rate, gpm & $0-25$ & MKV-11/2-sS \\
\hline W200 & Collector-HX to storage flow rate, gpm & $0-25$ & $M K V-1 \frac{1}{2}-\mathrm{SS}$ \\
\hline W201 & Storage to $\mathrm{H} / \mathrm{C}$ system flow, gpm & $0-23$ & MKV-11/2-SS \\
\hline W300 & DHW flow to load, gpm & $0-10$ & $M K V-3 / 4-s S$ \\
\hline W301 & Storage to DHW HX flow rate, gpm & $15-25$ & $M K V-1 \cdot s s$ \\
\hline W302 & DHW to HE-3 flow rate, gpm & $10-15$ & MKV-1-ss \\
\hline W400 & East fan coil water flow rate, gpm & $3-11$ & $M K V-1-s s$ \\
\hline W401 & West fan coil water flow rate, gpm & $3-11$ & MKV-1-ss \\
\hline W500 & East Arkla generator flow rate, gpm & $0-11$ & MKV-1-ss \\
\hline W501 & West Arkla generator flow rate, gpm & 0.11 & $M K V-1-s s$ \\
\hline W502 & East Arkla condenser flow rate, gpm & $0-10$ & MKV-1-ss \\
\hline W503 & West Arkla condenser flow rate, gpm & $0-10$ & MKV-1-ss \\
\hline W600 & East air duct flow rate, cfm & $1500-1900$ & Ellison $74 / 157 \mathrm{~A}(20 \mathrm{in.})$ \\
\hline W601 & West air duct flow rate, cfm & $1400-1750$ & Ellison $74 / 157 \mathrm{~A}(20 \mathrm{in.})$ \\
\hline EP300 & DHW auxiliary electric power, watts & $0-4500$ & PC5-29 \\
\hline EP500 & P.10, cooling tower pump \& fan \& control, electric power, watts & $0-3000$ & PC5-20 \\
\hline EP600 & $\begin{array}{l}\text { System operating power, watts } \\
\text { P-1, P-2, P-3, P-4, P-5, P-9, air compressor, system control circuitry }\end{array}$ & $0-9000$ & PC5-29 \\
\hline EP601 & East Arkla blower and controls, watts & 0.1450 & PC5-19 \\
\hline EP602 & West Arkla blower and controls, watts & $0-1150$ & PC5-19 \\
\hline $1-400$ & Auxiliary $\mathrm{H} / \mathrm{C}$ boiler natural gas flow, cu ft per $\mathrm{hr}$ & 0.250 & (not selected) \\
\hline
\end{tabular}




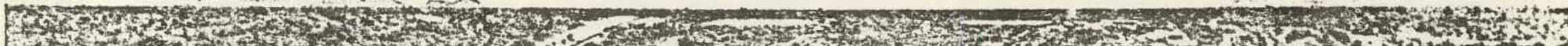

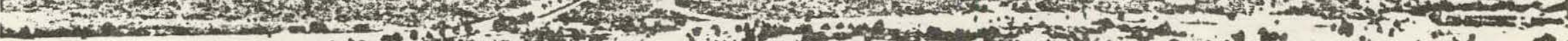

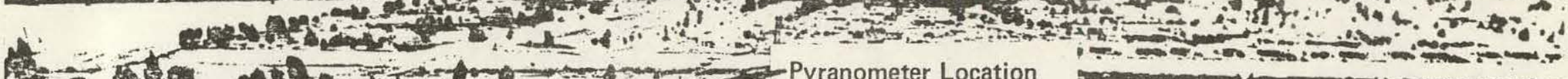

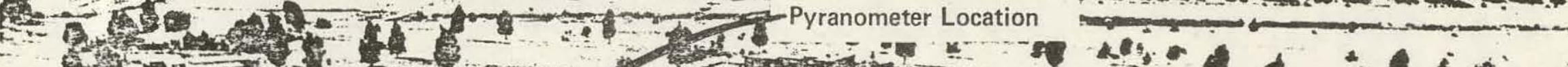

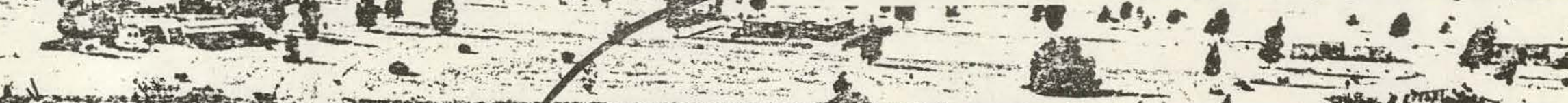

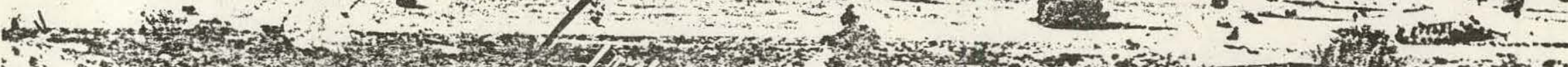

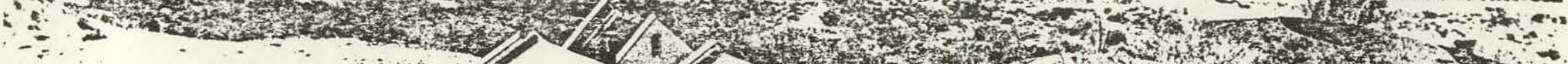

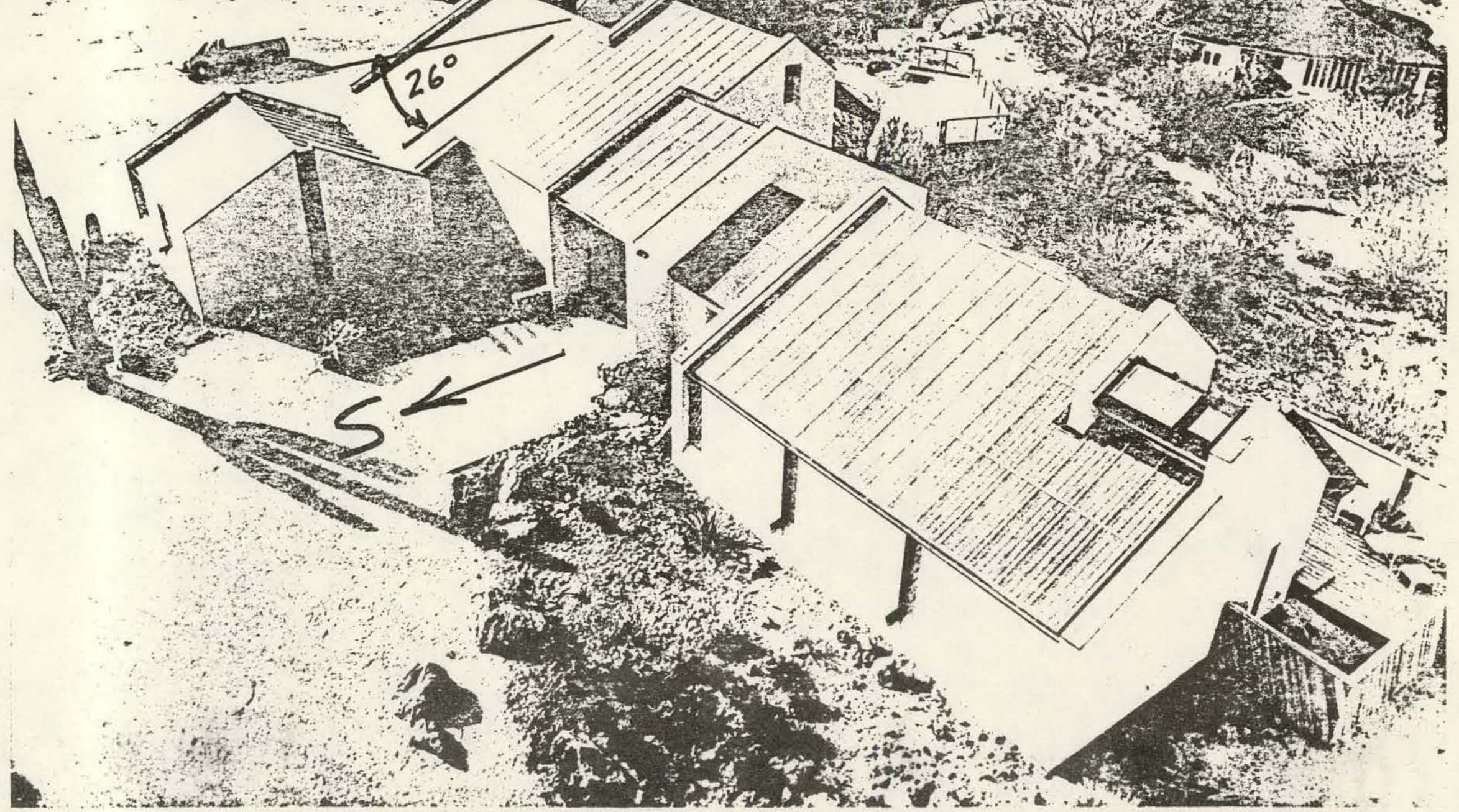

FIGURE 1. VIEW OF DECADE 80 SOLAR HOUSE SHOWING

COLLECTOR ORIENTATION AND PYRANOMETER LOCATION 


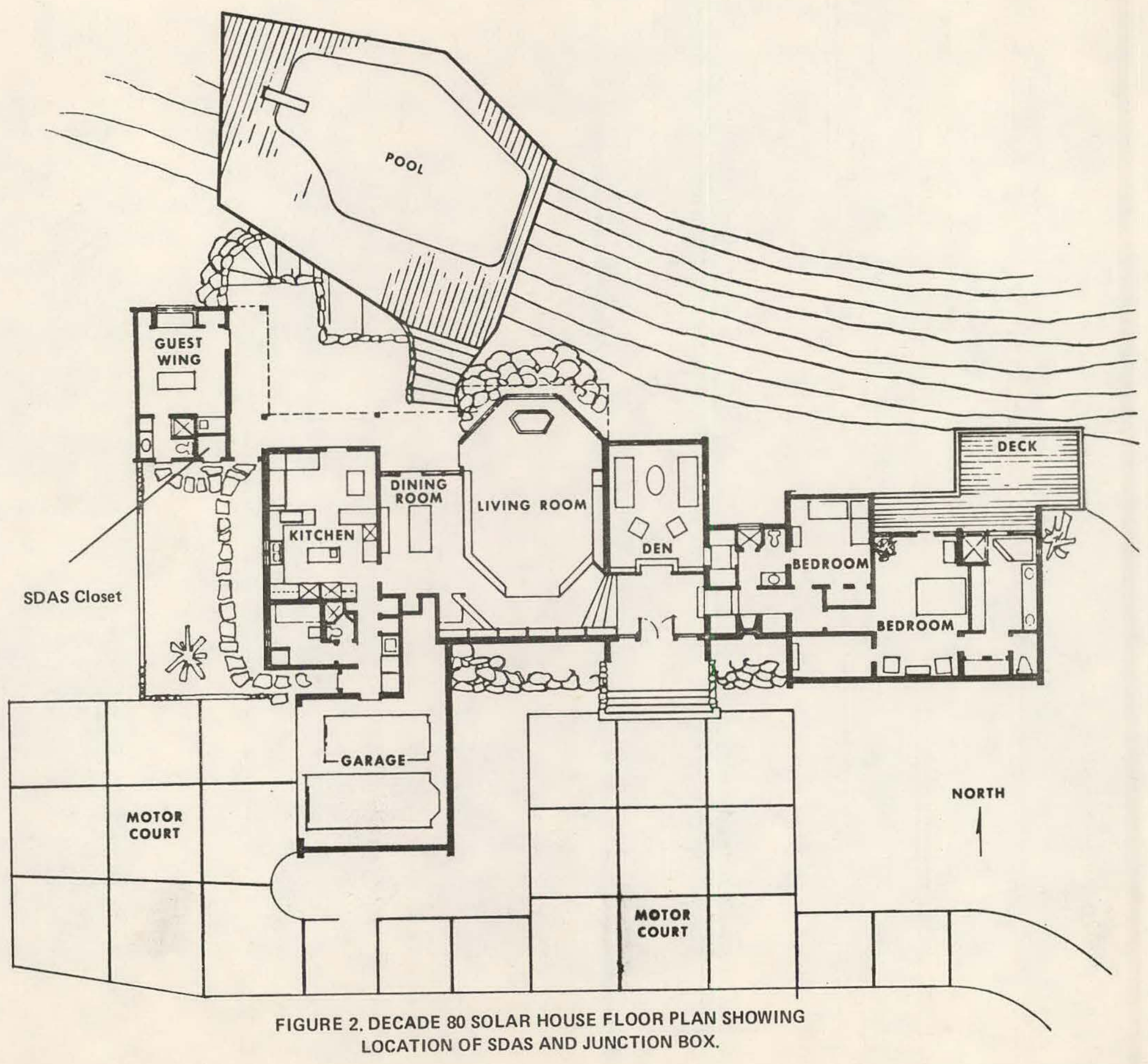


APPENDIX A 


\section{Copper makes solar energy right at home}

The new Decade 80 Solar House in Tucson. Arizona, features dozens of technological and design innovations highlighted by a beautiful copper roof to create a solar home that will meet the highest expectations of comfort and convenience.

Conceived and built by the Copper Development Association Inc., advanced market development arm of the copper and brass industry. the Decade 80 Solar House is designed to prove the practical value of sun power as an alternate energy source in an era of dwindling fuel supplies and rising energy costs.

On the sun side of the house. copper solar collectors are an integral part of the overall copper roofing system. These copper collectors are now commercially available and easy to install with today's tools and skills. Copper is the first choice for solar panels because it conducts heat more effectively and resists corrosion better than other feasible materials.

Unlike experimental solar structures, the Decade 80 Solar House is a real home-a year-round residence whose copper-based. solar-assisted climate control system utilizes solar energy for $100 \%$ of heating needs. and at least $75 \%$ of cooling needs.

Architect M. Arthur Kotch has designed the Decade 80 Solar House as a blueprint of bright ideas ahead in residential design and construction. Innovative products from participating sponsors in the building construction and home furnishing fields are everywhere. And so are copper. brass and bronze products that will continue to be hallmarks of high-quality construction-copper plumbing and wiring. copper metals for architectural and decorative uses, exterior and interior.

(A) The combination solar collector roof consists of $2 \mathrm{ft}$. by $8 \mathrm{ft}$ copper sheets and rectangular copper tubes fastened to them. both blackened for maximum absorbing power. Radiant heat is trapped in the collectors. transferred to water in the tubes and circulated by ITT Bell \& Gosset! pumps into a storage tank. This energy then is transferred as needed to Arkla Industries absorption chiller or to a fan coil unit for cooling or heating the house. Fiberglas ducts from Owens-Corning Fiberglas provide noiseless distribution of warm and cool air from the Arkla units The stored energy is used also for heating household water PPG Industries "Twindow" double glass covers the blackened copper collector panels to trap energy that is radiated back from the collector surfaces. A separate copper collector heats the pool.

Architect: M Arthur Kotch. A.I A

Interior Design: Ving Smith Interiors. A S I.D

Contractor: McLoughlin Contractors \& Engineers. Inc
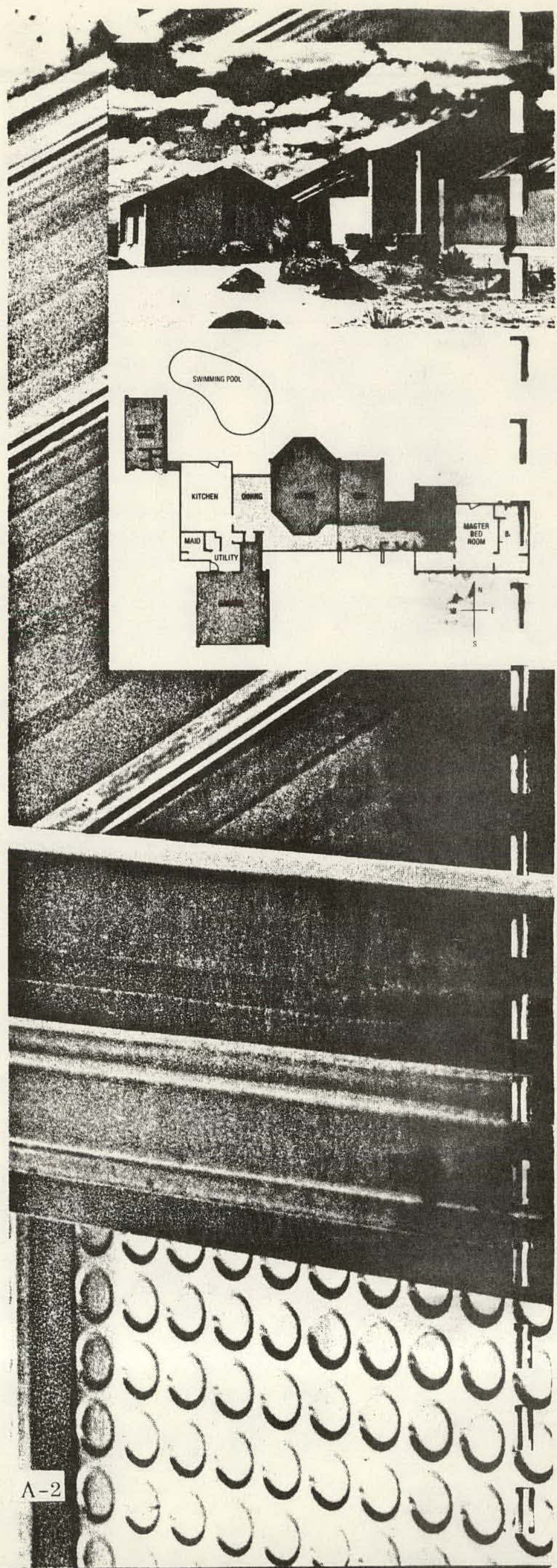

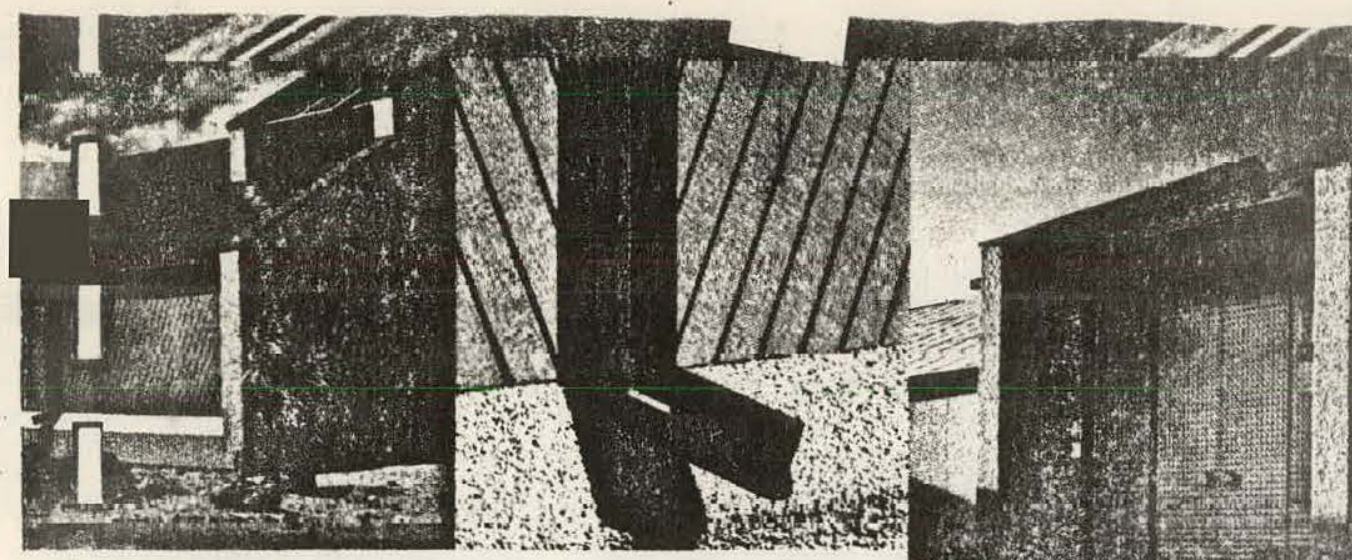

(B) The south side of the house is almost windowless to minimize the cooling load. Dramatic copper doors are fully insulated. Uwens-Čorning Fiberglas building insulation under the copper roof and in walls cuts heat gain and

F loss for maximum energy conservation. Grooved siding is U.S. Plywood's Roughtex T1:11 in desert-toned cedar. (C) Practical, stylish burnished-copper downspouts continue theme of natural colors and textures.

in

Floor plan fulfills desires of today's families for casual living and convenience. Openness of living areas sets a relaxed, informal mood.
1.

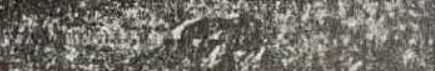

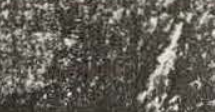

(D) Casting a warm glow of welcome are the main entrance doors, pulls and side panels of copper. Out-of-sight Schlage Electronics access system eliminates keys by sensing presence of a coded card held near sensor unit in wall. Side windows flanking doors are narrow heat-reflective Solarcool Bronze Twindow units from PPG Industries. Native Arizona copper ore is in the foreground.

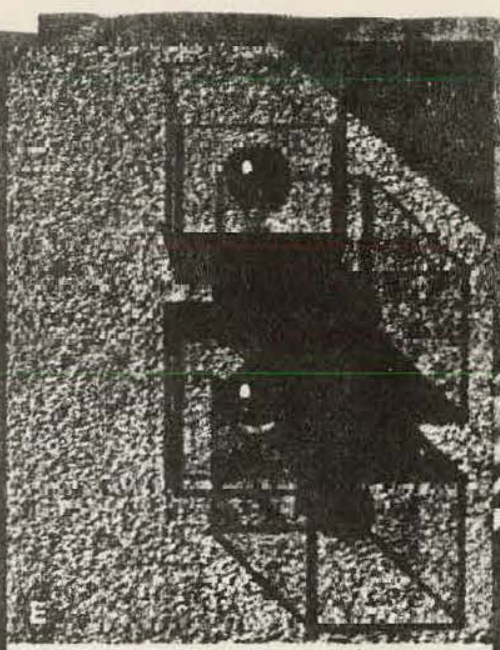

(E) Elegantbronze side lights contrast beautifully with durable exterior cladding of U.S. Plywood's Sanspray, a factoryfinished plywood panel coated with decorative stone chips in a protective epoxy resin.

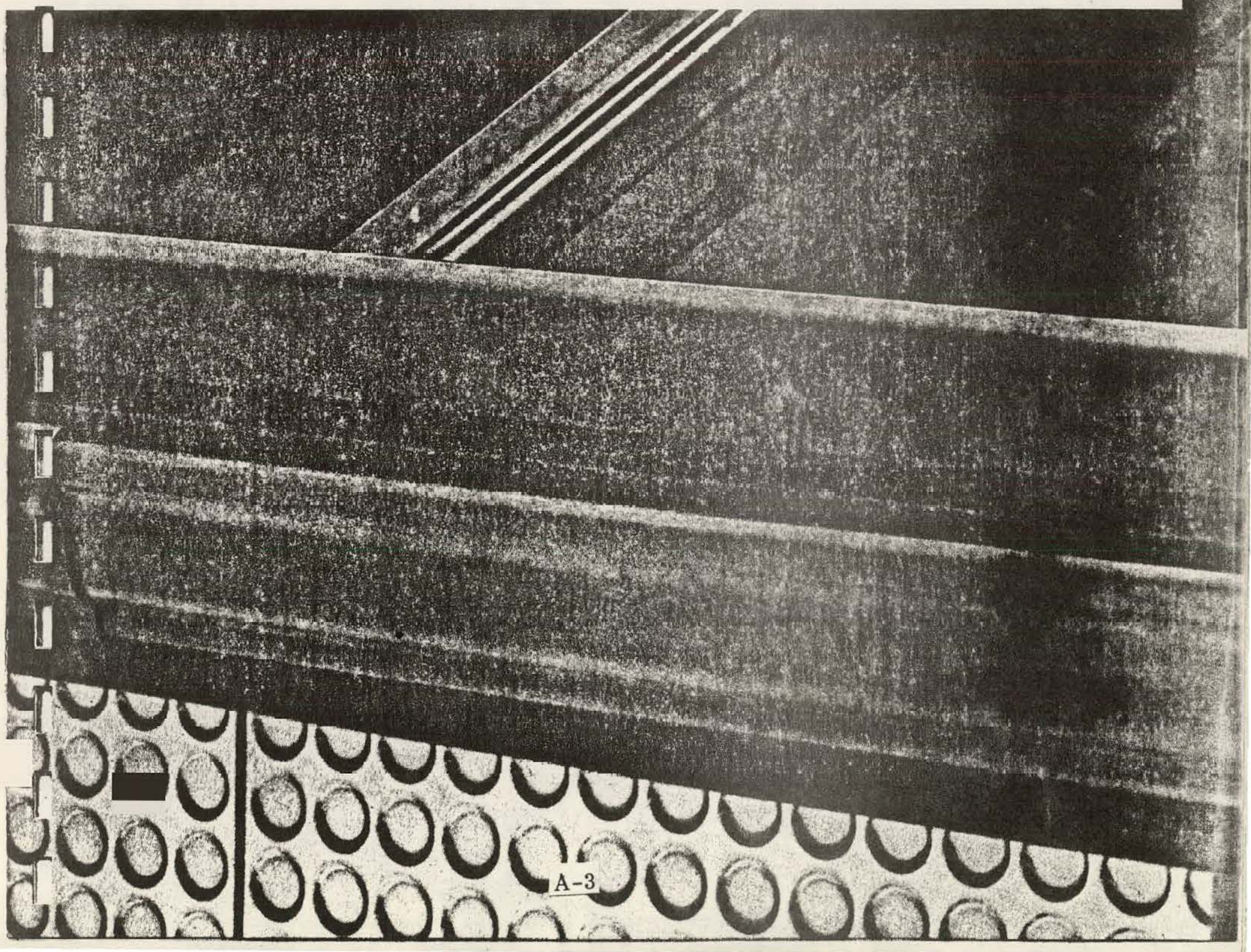




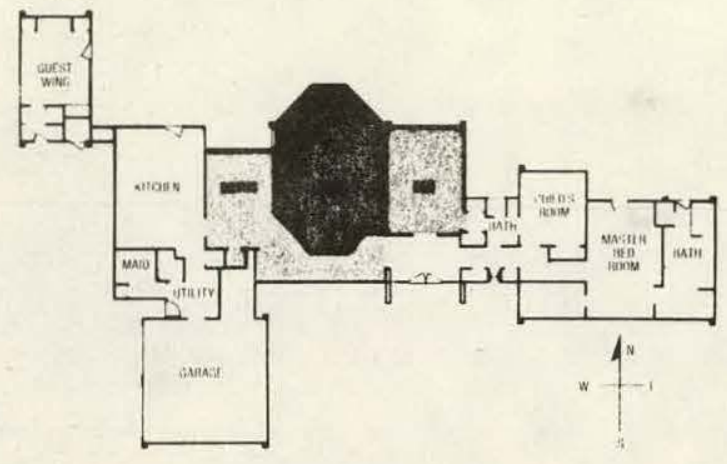

\section{Elegant, arefree living, solar-style}

The sun-splashed living areas of the Decade 80 Solar House present a glowing showcase for today's emerging trend in home decor-" neutrals and naturals." enhanced by the warmth and beauty of copper. brass and bronze.

Every room is alive with decorative ideas and furniture designs for todays elegant yet informal lifestyles, coordinated by interior designer Ving Smith. A.S.I.D. Each room has a dramatic view overlooking the beautiful Tucson National Golf Course.

Colors and textures reflect the desert environment and the traditions of the American Southwest-subtle tones of sand. beige. sky blue and sagebrush. Woods display their natural finishes or are lightly stained. Floors

(A) Cubes and columns of mirrored copper and brass, enriched with an abstract. inlaid solar design. were toreated by Ving Smith as the house s" signature" andused here as scîlpiture in the foyer with a Navajo Indian bowl. The entrance hall and living room walls are distinctive light- hickory paneling from the elegant U S. Plywood Weldwood Collection Indian Artifacts: Navajo National Arts \& Crafts Council

B) That special glow of a candlelight dinner is reflected by copper plates. serving dishes, brass candleholders and brass wall covering

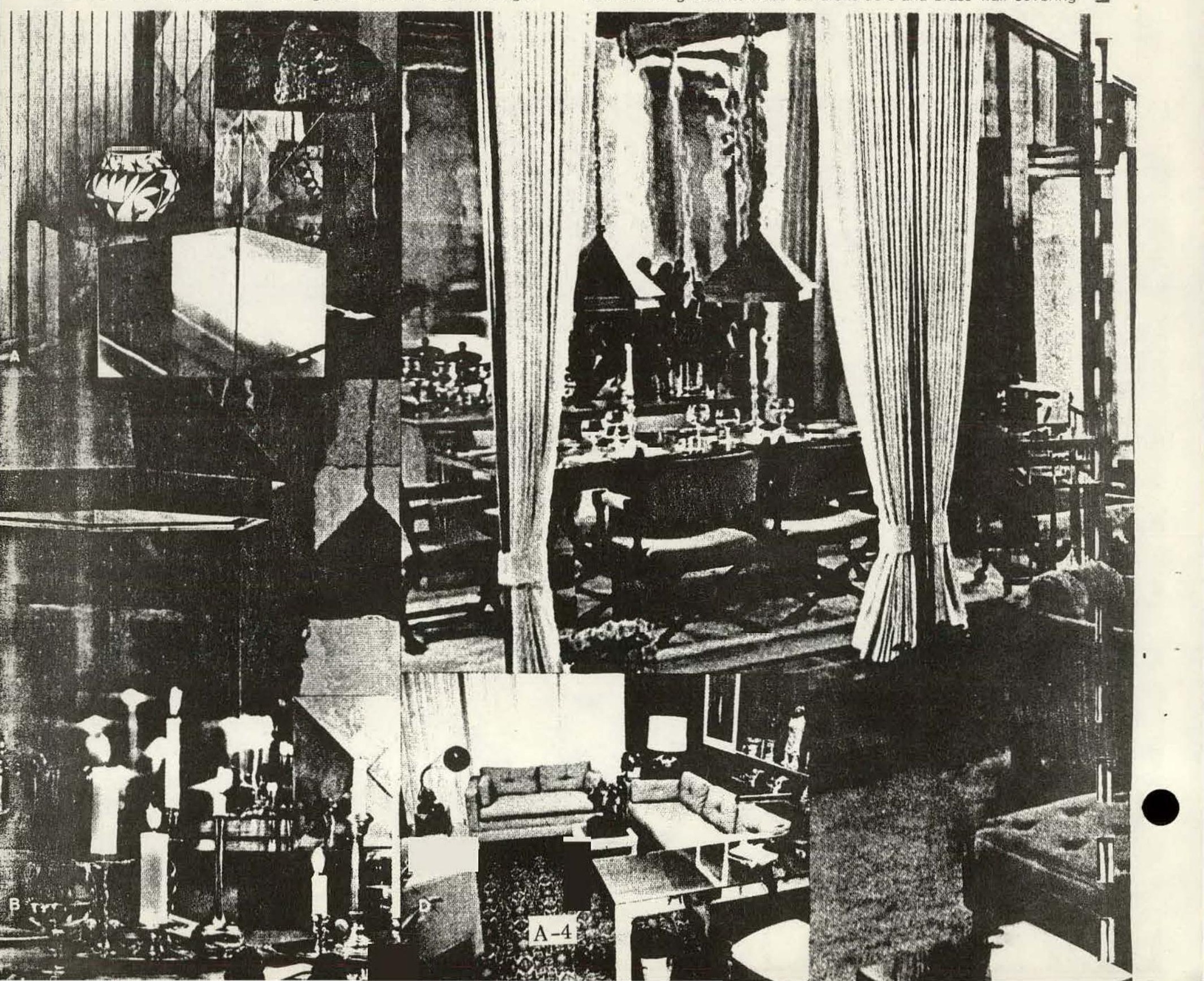


I are of ceramic tile from member corr. ies of the Tile Council of America. And decorative accents are those of the warm-tone metals-copper, brass, bronze.

Most furnishings in the Decade 80 Solar House have been selected from the vast resources of Burlington Industries. the largest and most diversified manufacturer of these products for the home.

Styles are right in tune with today's eclectic tastes. In

F the dramatic sunken living room. contemporary pieces from the Burlington Stendig Collection contrast excitingly with prototype furniture designs in copper and brass, created specially for the Decade 80 Solar House.

Tying together living areas is the fresh look of ceramic floor tile. A rich, durable amber-tone tile sweeps from the front steps through foyer. living room and dining room to enhance the open plan and create a natural backdrop for an array of Lees carpets from Burlington.
Beneath bronze $c$ deliers, a mirrored brass dining table is the room's natural focus, beautifully at home with Burlington's director's-type dining chairs. Floor-toceiling windows and doors are thin-line bronze framed. Double glass and thermal-break frames conserve energy.

In the dining room and throughout the Decade 80 Solar House, Scotchgard" Brand Fabric Protectors from $3 \mathrm{M}$ Company are on the job. keeping upholstery. draperies and even wallcoverings fresh-looking and soil-free If a spill occurs, it will usually bead up on the fabric and can generally be blotted away without leaving a stain.

Scotchgard Drapery Protector safeguards all draperies in the house which are woven of Owens-Corning Fiberglas yarn as are wall coverings. Fire-safe Burlington House draperies of Fiberglas in icy white dramatize windows. Versatile Fiberglas reproduces the look and feel of traditional fabrics.
(C) A soaring copper fireplace, copper and brass hearth equipment. decorative copper bowls and brass lamps reflect the warmth of the fireside. Shimmering mirrored brass wall sets the stage for gracious dining and entertaining. Brass pole system separates living and dining areas with Burlington's draw draperies for more privacy when desired. (D) In the den/study, the mirrored-copper desk blends with the warmth of a patterned rug and flooring of glazed ceramic tile. Paintings. sculpture: Harlan Gallery. Copper cloisonne: Margaret Seeler.

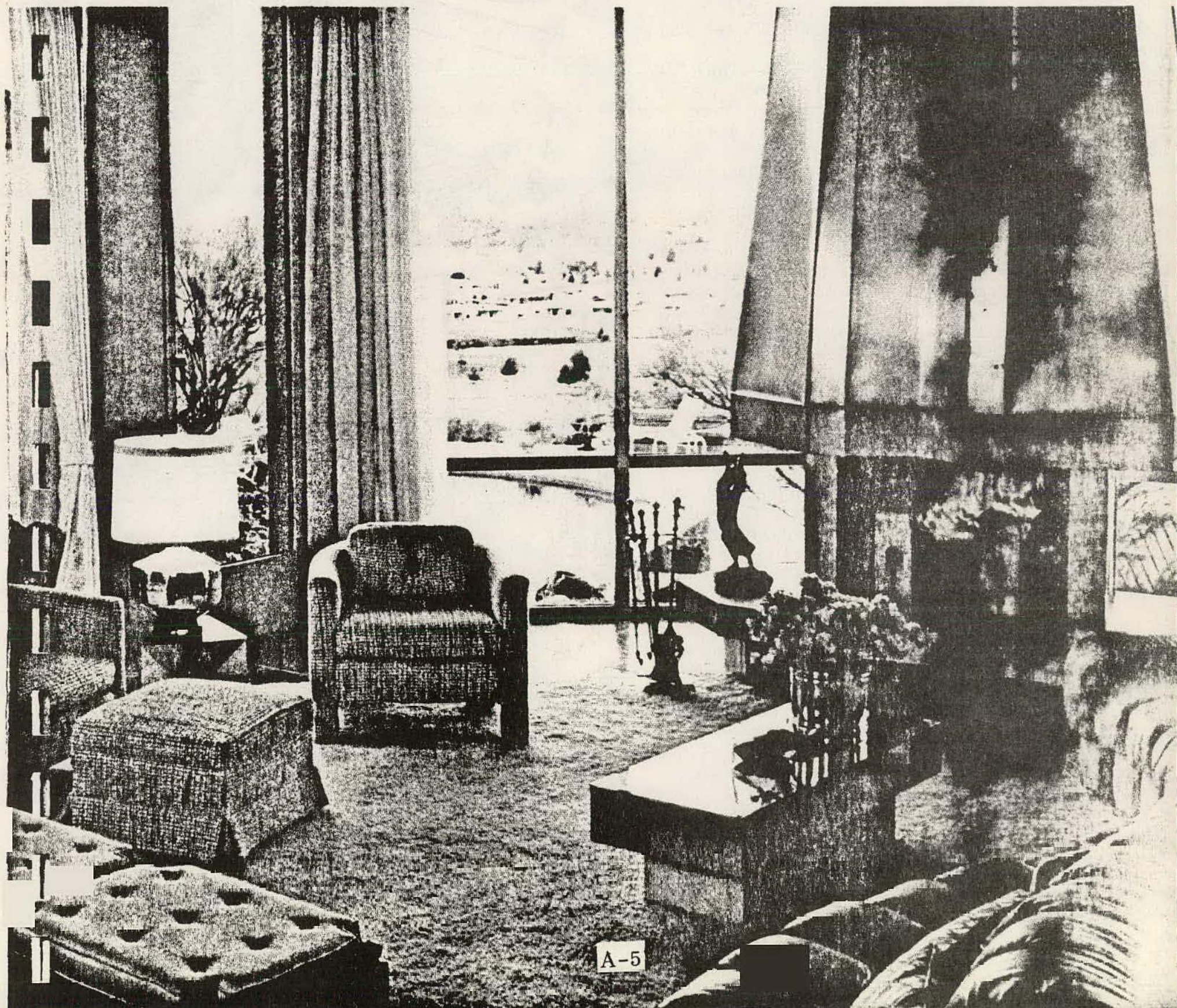




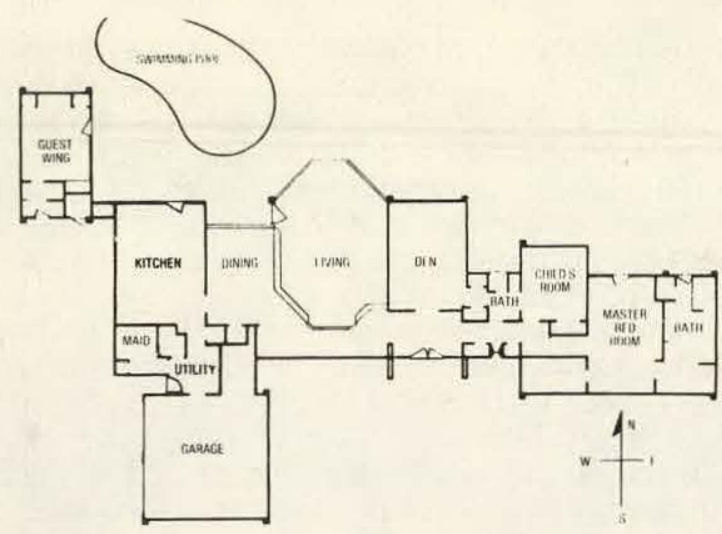

\section{Copper Kitchen:} Everything new under the sun

Ultimate convenience with ultimate energy conservation was the design challenge posed by the Decade 80 Solar House's kitchen and utility rooms. The result is a "dreamcome-true." step-saving environment built around the central food preparation island

Every appliance in these bright. friendly copper-accented rooms was selected from among the most advanced energy-conserving designs available. Solar cells on the house's roof power the kitchen's TV set. wall clock and some small appliances

Amana's "Energy Saving Refrigerator" uses only 2.9 kilowatt hours of electricity per day-little more than a single 100-watt light bulb. Amana's companion "Free-OFrost Freezer" stops any energy-wasting frost build-up before it starts.

An advanced-design Amana "Radarange" microwave oven also cuts energy consumption $\mathrm{Nith}$ cool micr wave cooking. there's no energy wasted heating the oven before cooking begins.

The novel Jenn-Air convertible grill-range offers the beauty of glass-ceramic cooktops in modules which unplug and convert into a single or double grill. Accessories transform the unit into a rotisserie. French fryer. griddle or shish kebab broiler. Built-in proximity ventilation eliminates overhead exhaust hood. In guest wing is a Jenn-Air deluxe single grill.

For cleaning up after mealtime or entertaining there's a Maytag food-waste disposer and a built-in dishwasher engineered for energy-saving operation and highlighted by a copper front. Its rinse-and-hold. crystalware and plastics cycles are important energy conservers.

Color-coordinated ceramic floors, countertops and backsplashes throughout are from the Tile Council of America. Cheerful canary yellow floor tiling has a slipresistant glaze. Crisp white square-tiled countertops are perfect foil to the elegantly-styled AmericanStandard "Fiesta" triple bowl sink.

(A) Step-saving planning puts triple sink, copper fronted Maytag dishwasher, and countertop Jenn-Air grill-range all within easy reach Undercabinet lighting brightens tile work surfaces

(B) For conventional baking. there's an extra-large Jenn-Air deluxe twin oven, with clock-controlled baking energy-hoarding continuouscleaning interior. Informal eating area beyond opens onto poolside:

(C) Copper-fronted Amana freezer and refrigerator are hancly to) energy-conserving Amana "Radarange" microwave oven. Central to all is butcher-block topped food preparation island

(D) Down corridor in utility area. two more energy-saving appliances Maytag's automatic all-fabric clothes washer handles any time and temperature cycle. Maytag's electronic control dryer automatically measures moisture content of clothes. economically cutting off current as soon as load is properly dried. Utility sink by American Standard

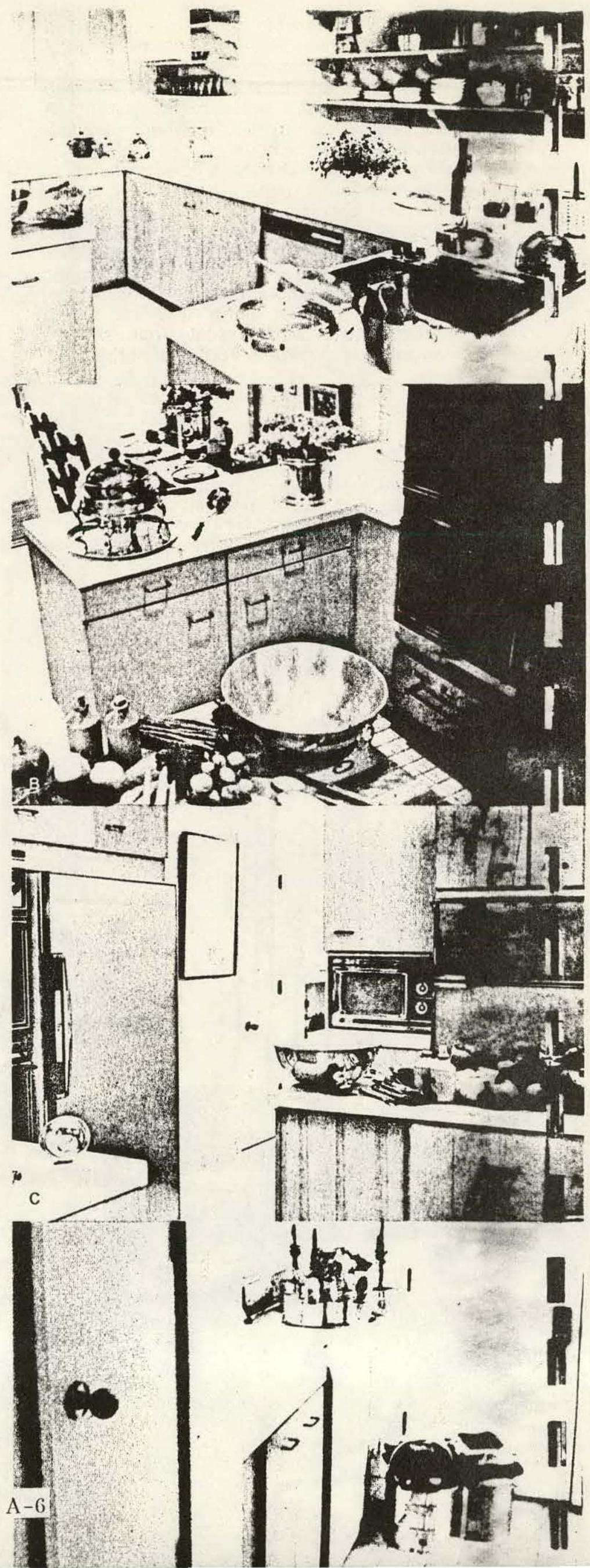




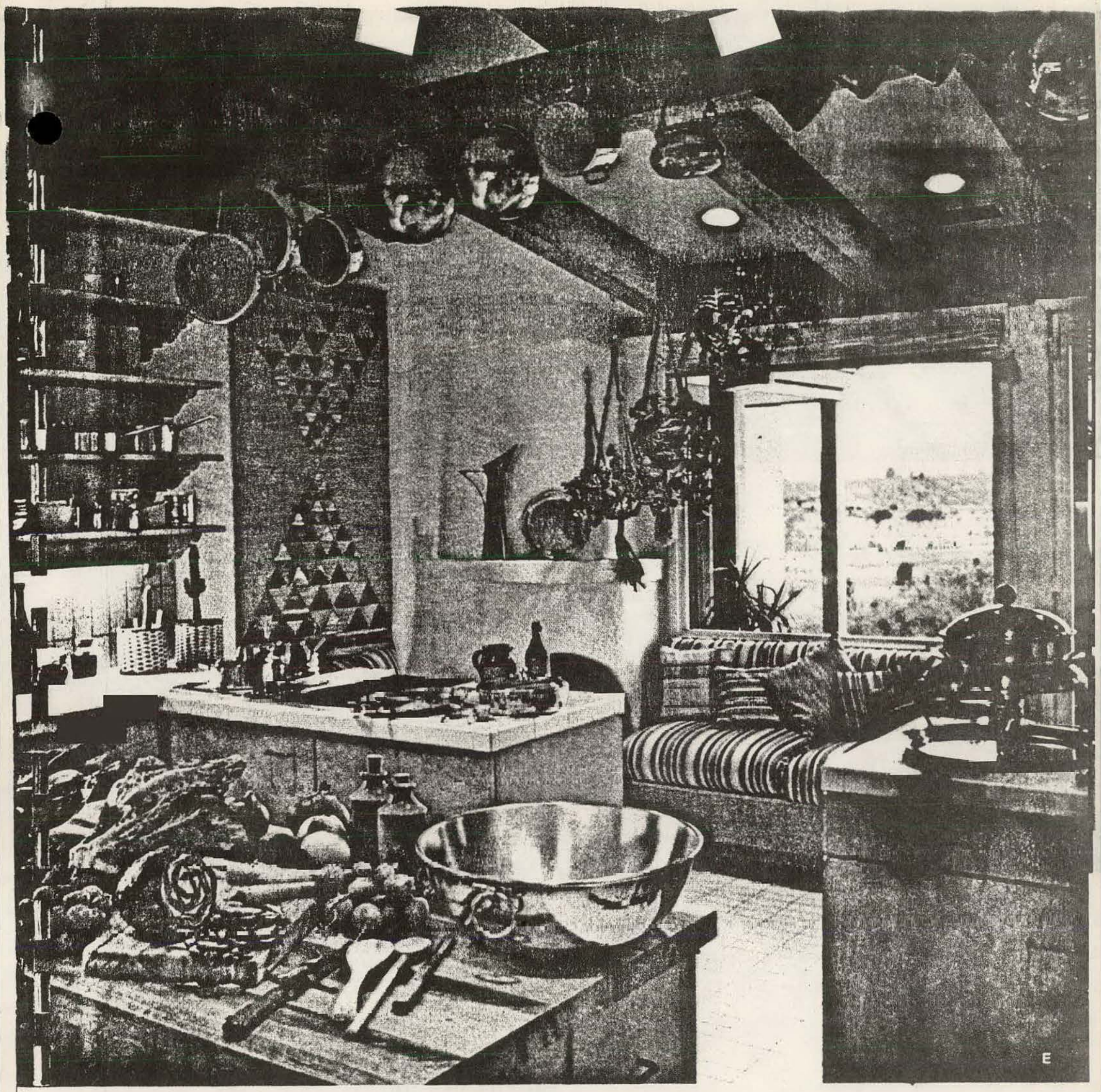

(E) Above in the Decade 80 Solar House kitchen are professionalquality copper pots. pans and kitchen tools-time-tested companions to fine cooking. In the 1980 's, as always, gourmet cooks will be cooking with copper because of its even heating qualities. Beyond, charming family room with adobe-type corner fireplace and built-in banquettes covered in Burlington hot Mexican striped fabrics, made carefree by $3 \mathrm{M}$ Scotchgard Protectors. Copper-theme accents help make this a delightful area for breakfasts, snacks and informal entertaining. Copper wall hanging: Yvonne Forbath. Breakfast area paintings: Chabela. 


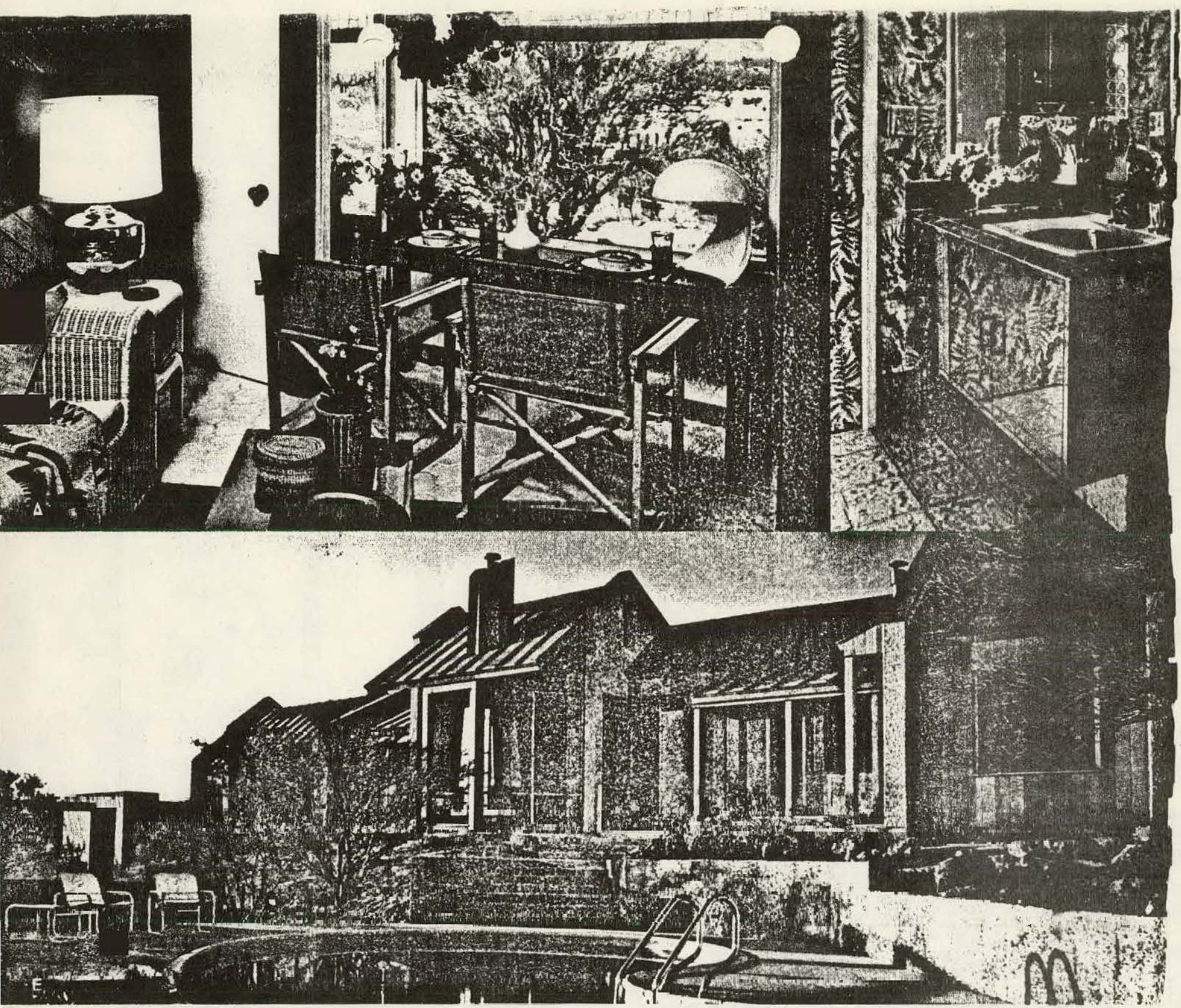

(A) Guest wing decomative motif is set by paneling of cinnamon brown California redwood lumber. dramatically applied on the diagonal to walls and ceiling. Accessories are in varying tones and texlures of the copper metals: copper. brass and bronze.

(B) The mirrored copper sink enclosure and ceramic tile floor adif touches of practical elegance to the child's bathroom Unseen servants: efficient, lifetime copper and brass plumbing
(C) Furniture and decor in child's bedroom reflect younger tastes Walls and ceilings are of U.S. Plywood's Wayside Inn paneling in birch. with mismatched plank look accenting the natural knots and burls of real wood. RCAs solar-powered TV addis to room's enjoyment

(D) Master bath features super-sized. 42-inch-wide : Ultra Bath Bathing Pool by American-Standard. his and hers "Ovalyn "lavatories highlighting the expanse of cobalt blue musaic tile on counter top

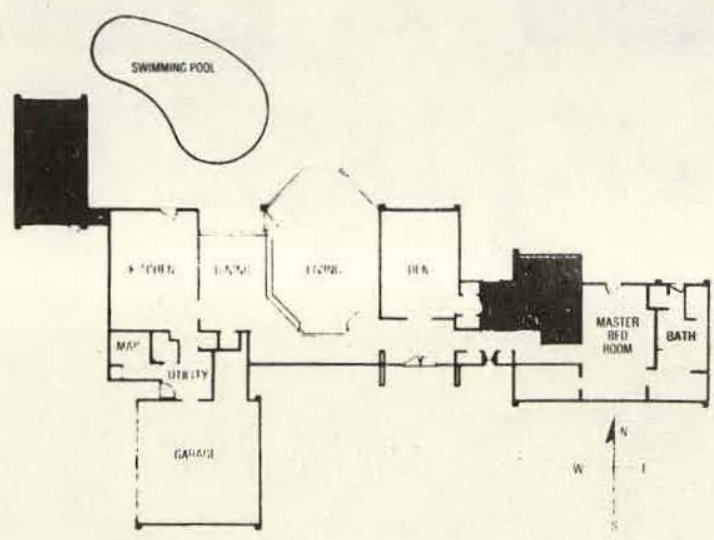

\section{Solar-home sunning, bathing and sleeping}

Sunning. bathing and sleeping areas in the Decade 80 Solar House continue the note of luxury appropriate to America's most innovative home.

Opening onto the poolside area is a guest wing. with its own private entrance. kitchenette and bath. Copper solar panels on the south-facing cathedral ceiling are part of a separate solar energy system for heating or cooling the pool.

The entire guest wing floor is surfaced with "Corsican" design. curvilinear white glazed tile. The guest wing's window wall. as with all north-oriented glass. is PPG tempered "Solarbronze Twindow" insulating glass units 

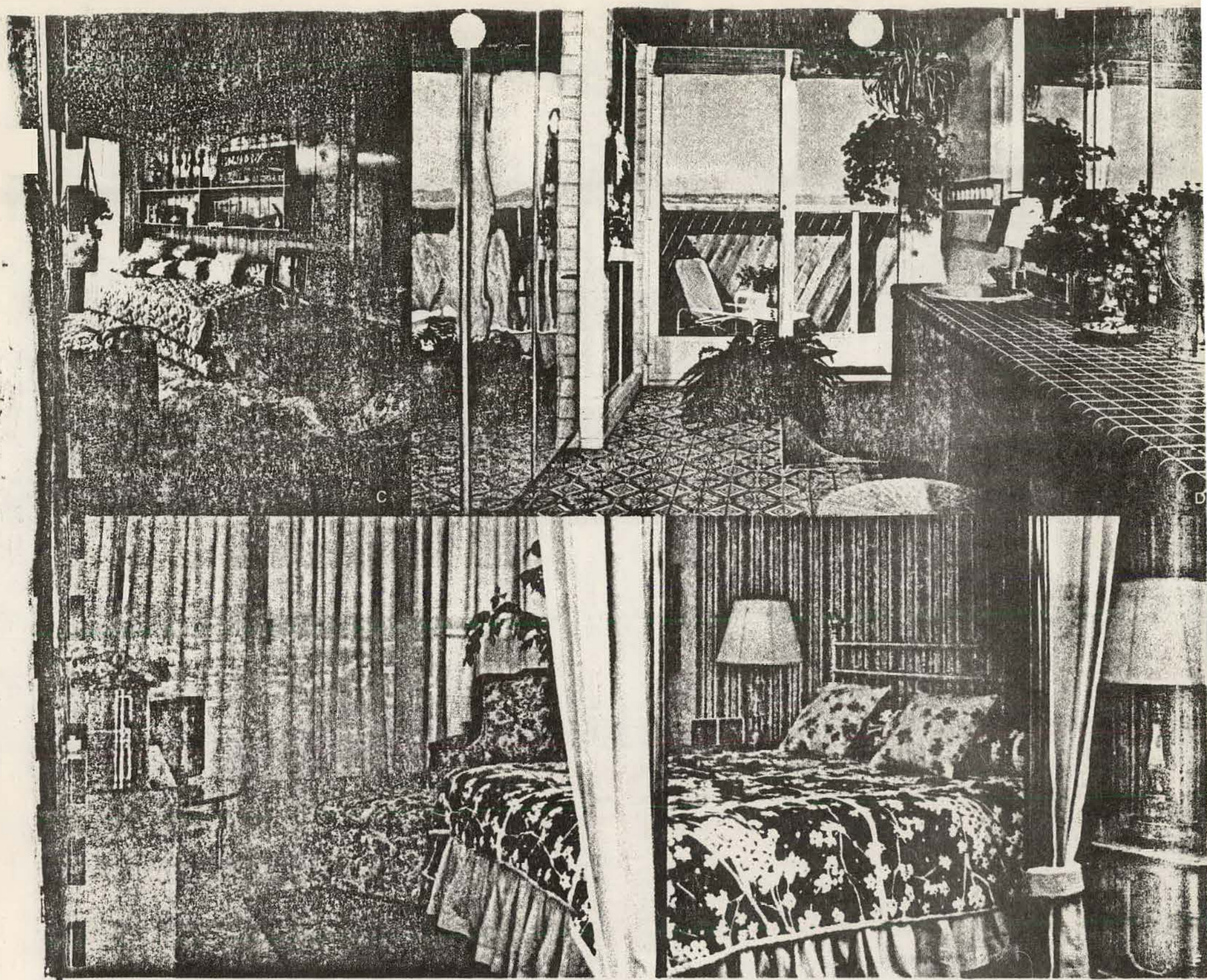

Light cỳlinders are ordinary copper plumbing tube cut to desired length

Outside: private California redwood deck

(E) Automatic poolside "servant" skims debris from water surfaces and continuously chlorinates water. California redwood is natural choice for pool decking and fencing and exterior siding of the guest wing. Copper roof. U S. Plywood Sanspray cladding complete natural look

which reduce heat gain or loss to half that experienced with clear single glass.

Outdoor living in the Decade 80 Solar House is as enjoyable and carefree as technology can make it. The natural center for entertainment and recreation is the family-sized, kidney-shaped "Buster Crabbe" swimming pool by Cascade Industries. This solar-heated "Capri" design pool has a mosaic-patterned bottom of light-todark blue and blue sidewalls, perfect reflections of the Arizona sky.

In the child's bath. American-Standard fixtures reflect a casual style. Lavatory is the self-rimmed "Aqualyn". water closet the one-piece "Concord", both in blue. Fittings and faucets are gold-plated brass

In the dramatic master bath. high-style AmericanStandard fixtures, faucets and fittings take center stage. with blues and copper metal hues predominating.

Distinctive furnishings linens and wall fabric from Burlington House create a mood of worldly sophistication and fashion in the Decade 80 Solar House s master bedroom. Decorative mirrored-brass pole system separates sleeping area from dressing area and bath $A$ fire sprinkler system protects master bedroom and all other rooms

An oversized American-Standard bathing tub-pool gives extra room for relaxing. A built-up back support and beveled headrest make it a sybarite's delight.

Water closet and bidet are sleek new low-profile designs. Floors are of dramatic. Aztec-inspired ceramic tile. Faucèts and fittings are again gold-plated brass. Closet doors are clad in mirrored copper.

Contrasting in color and texture are the walls and ceiling of natural all-heart California redwood. Red wood's superior insulating properties are important here and throughout the Decade 80 Solar House - it insulates better than gypsum board, plaster or cement block.

Accessible only from the master bath is a secluded sundeck for private sunbathing. Fencing and decking are of economical garden grades of California redwood one of the world's most weatherable woods. Its rustic texture extends the house's theme of natural materials. 

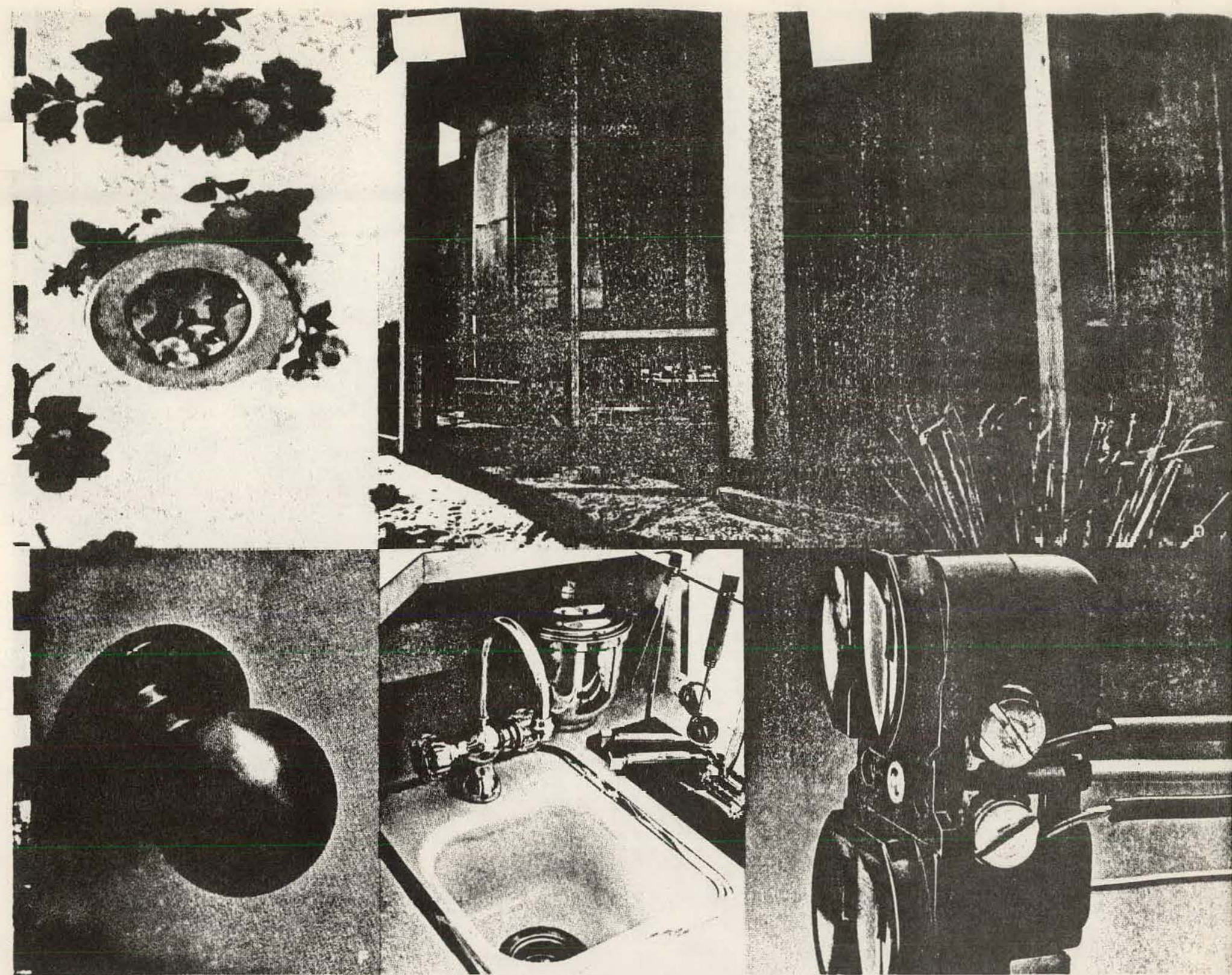

air conditioner condenser to help increase solar efficiency

(F) Schlages highly contemporary "Ball" lock in oil-rubbed bronze provides warmth and beauty throughout the house

(G) American-Standard party sink in living-area bar features elegant look of solid brass gold-finished fittings

(H) Copper wiring is sign of a quality home Copper's installation ease and lifetime reliability are well-known It is the standard for all types of buikdings Copper remains the only wiring approved by all cories

In addition to the sun-powered climate control system. the Decade 80 Solar House contains a small separate system directly converting solar energy to electrical energy. Silicon photovoltaic cells developed by Solar Power Corporation are mounted on the master bathroom roof, convert the sun's energy directly to low voltage power for selected uses. Electric power for lighting. cooking and appliances is utility-supplied.

Copper plumbing and copper electrical systems provide the Decade 80 Solar House with high performance reliability. For plumbing and electrical uses. copper is the standard of quality, accepted by more building codes than any other material. Architects and engineers also know that copper is more economical overall.

Copper systems for electricity. plumbing, fire sprinklers and solar energy are the lifeline of the Decade 80 Solar House built with materials and technology which are available today.

\section{Copper Development Association Inc.}

405 Lexington Avenue

New York. N.Y 10017 (Please print, as this is your mailing label)

Please send more information on:

I copper solar energy systems 11 copper consumer products

I other products

Name

Company

Position

Street

City

State

Zip 
Decade 80 Solar House Participaling Sponsors: Amana Refrigeration, Inc. micruwave uven, refrigerator. freezer $\square$ American-8tandaró Plumbing

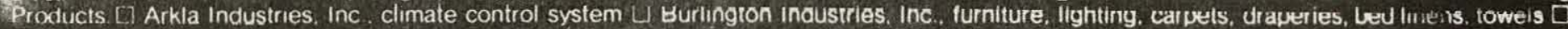
California Redwood Association interior paneling. fencing, decking and siding [ Cascade Industries Incorporated, swimming poo! i ITT Bell \& Gossett. Fluid Handling Division. centrifugal pumps and heal exchangers 1$]$ Jenn Air Corporation, cooking range. oven, and grill [1 The Maytag Company, washer. dryer. food-waste disposer. and dishwasher [ Owens-Corning Fiberglas Corporation. Decorative and Homefurnishings Divisıon. Fiberglas for the draperies. wallcovering, and bedspreads $\square$ Owens-Corning Fiberglas Corporation. Home Building Products Divisıon. F re glas insulation and Fiberglas duct system 1. PPG Industries, glass for solar panels, windows, and doors $\square$ Schlage Lock Company, electronic , ocking device and insksets $113 \mathrm{M}$ Company (Scotchgard Products), supplier of Sculchigard Protectors for upholstery, draperies, and wallcoverings $\square \mathrm{T}$ le Council of America. exterior and interior tiles $\longleftarrow$ U S. Plymood. Division of Champion International, exterior cladding and panels, intei ur paneling.

ol

I $\rightarrow$ COPPER DEVELOPMENT ASSOCIATION INC (1) A

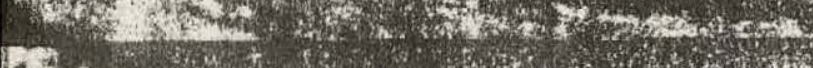

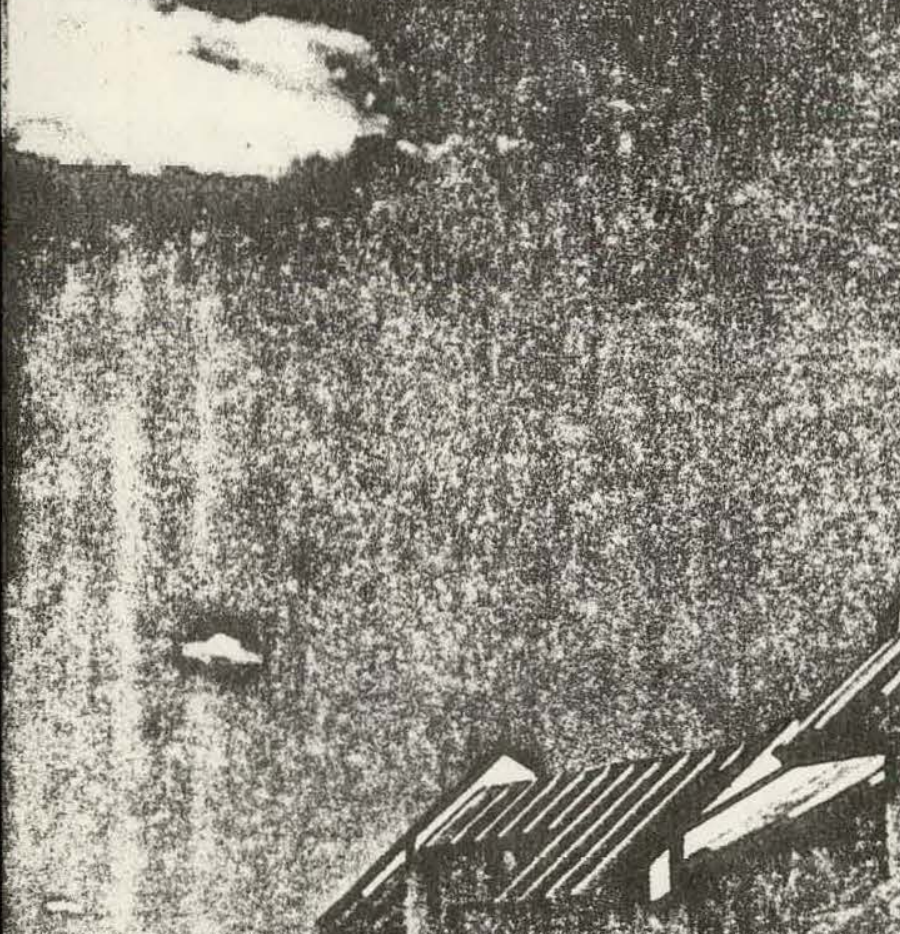

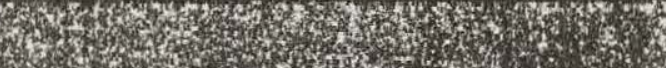
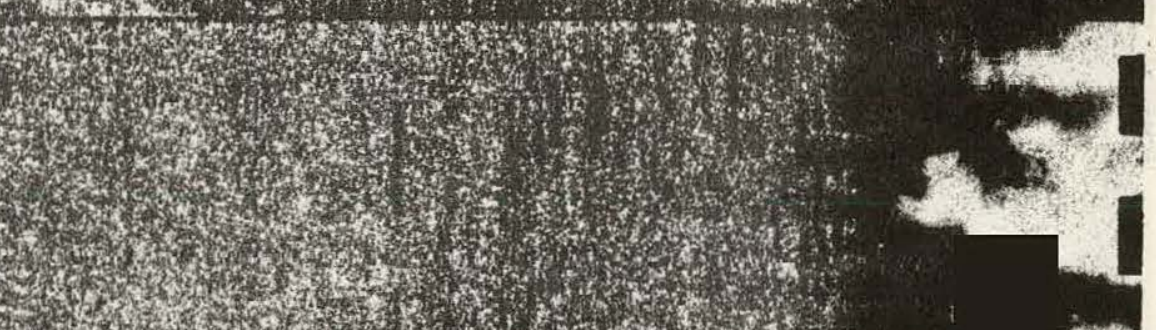

7. thing

.

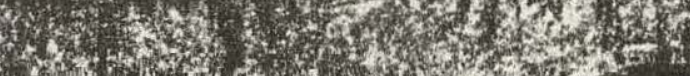

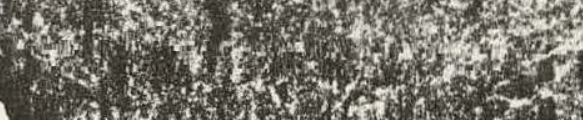

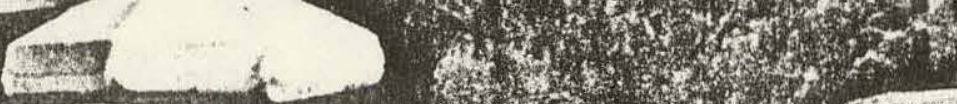
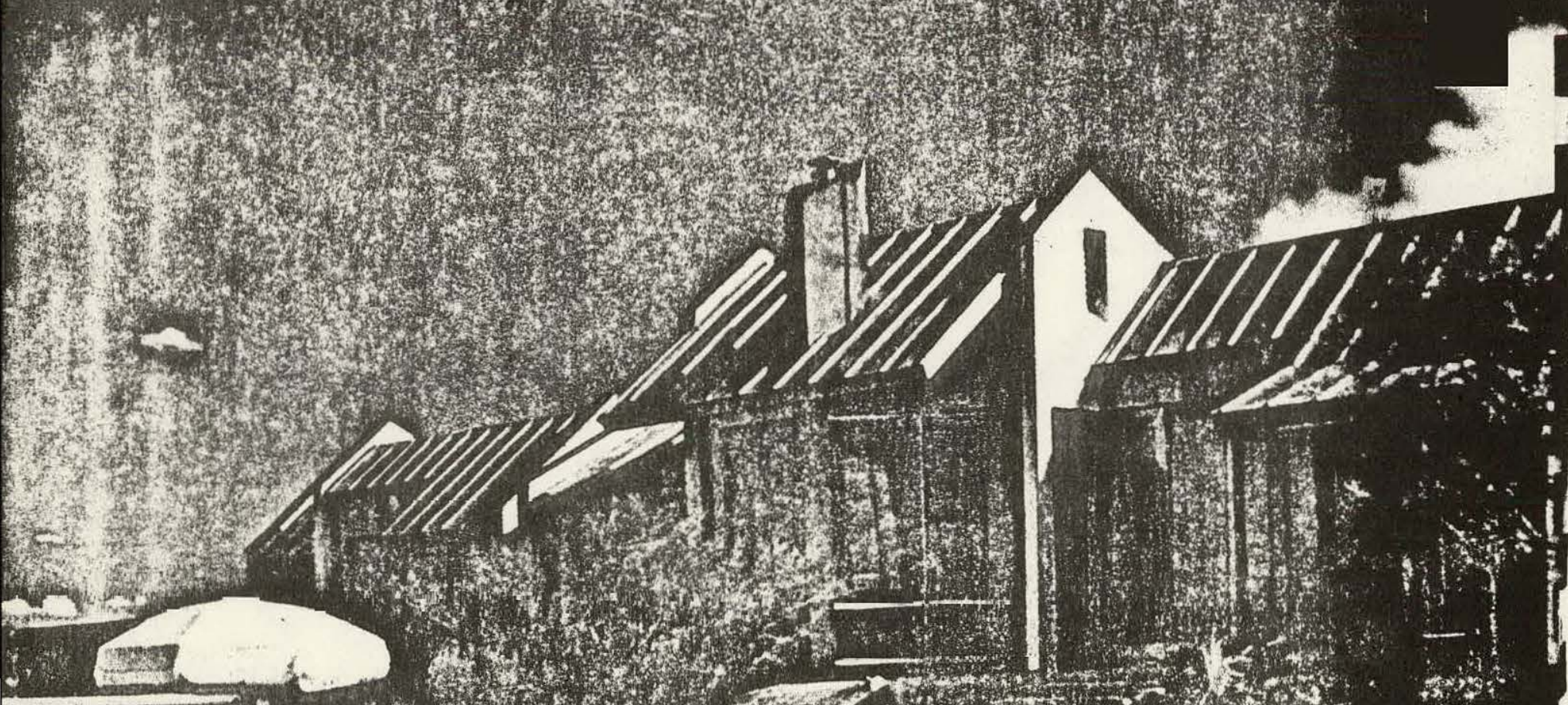

(3) -1

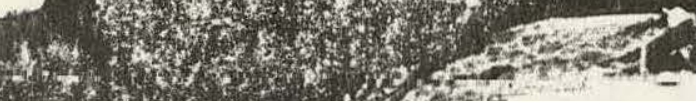

(4)

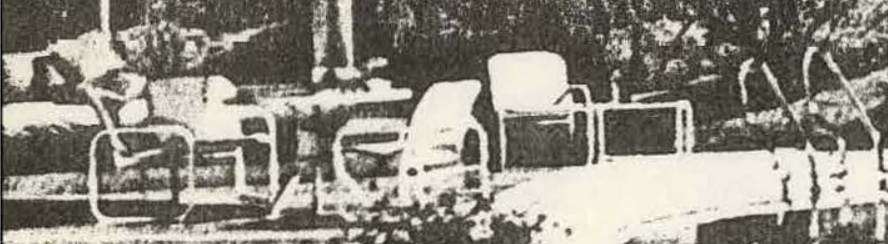

(

y)

F.

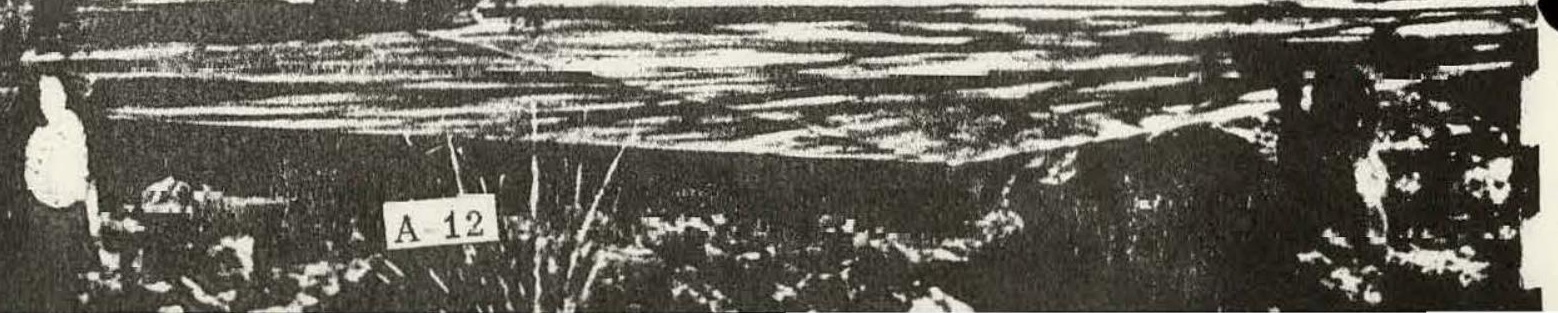


APPENDIX B 


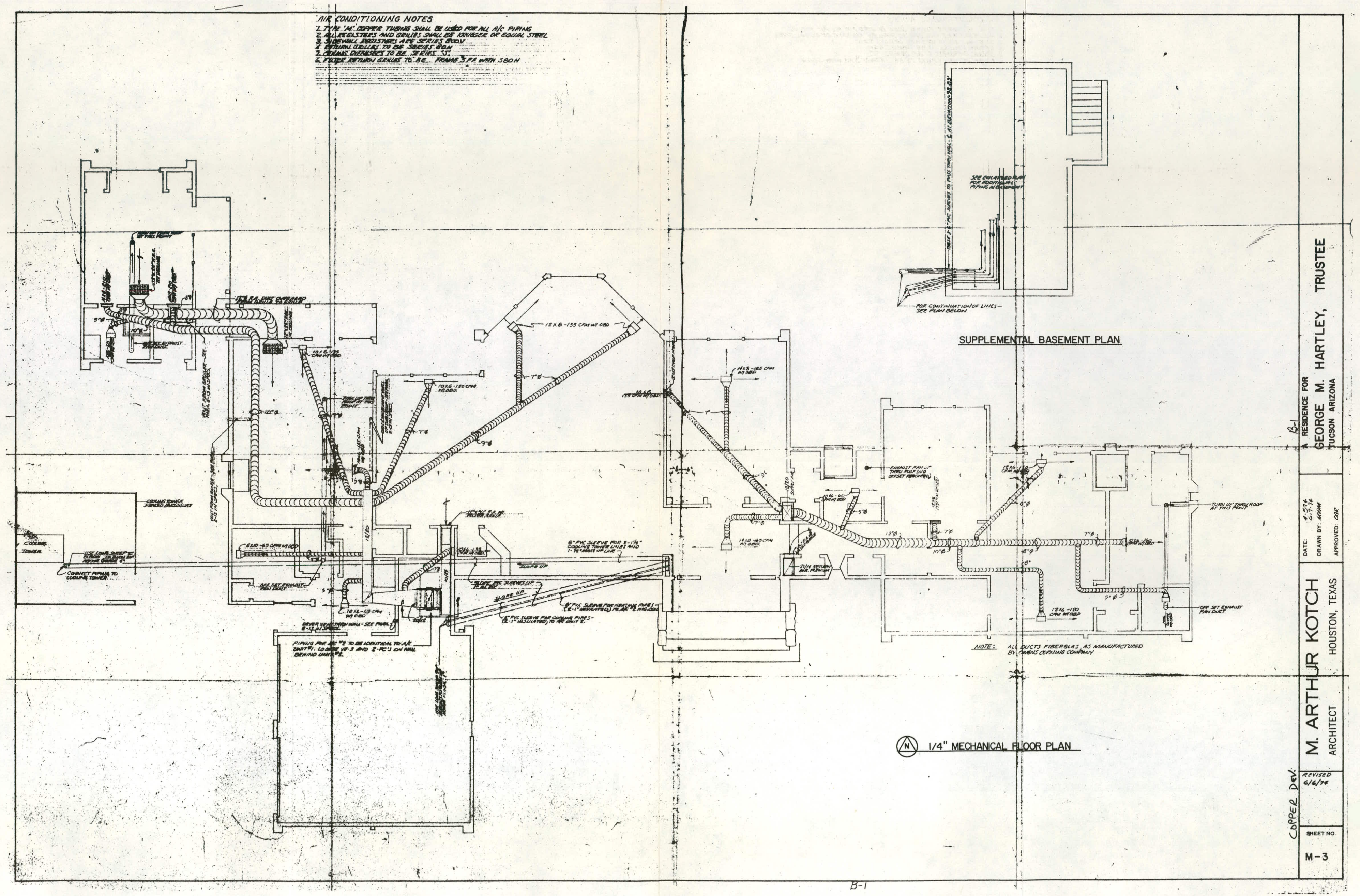


APPENDIX C 


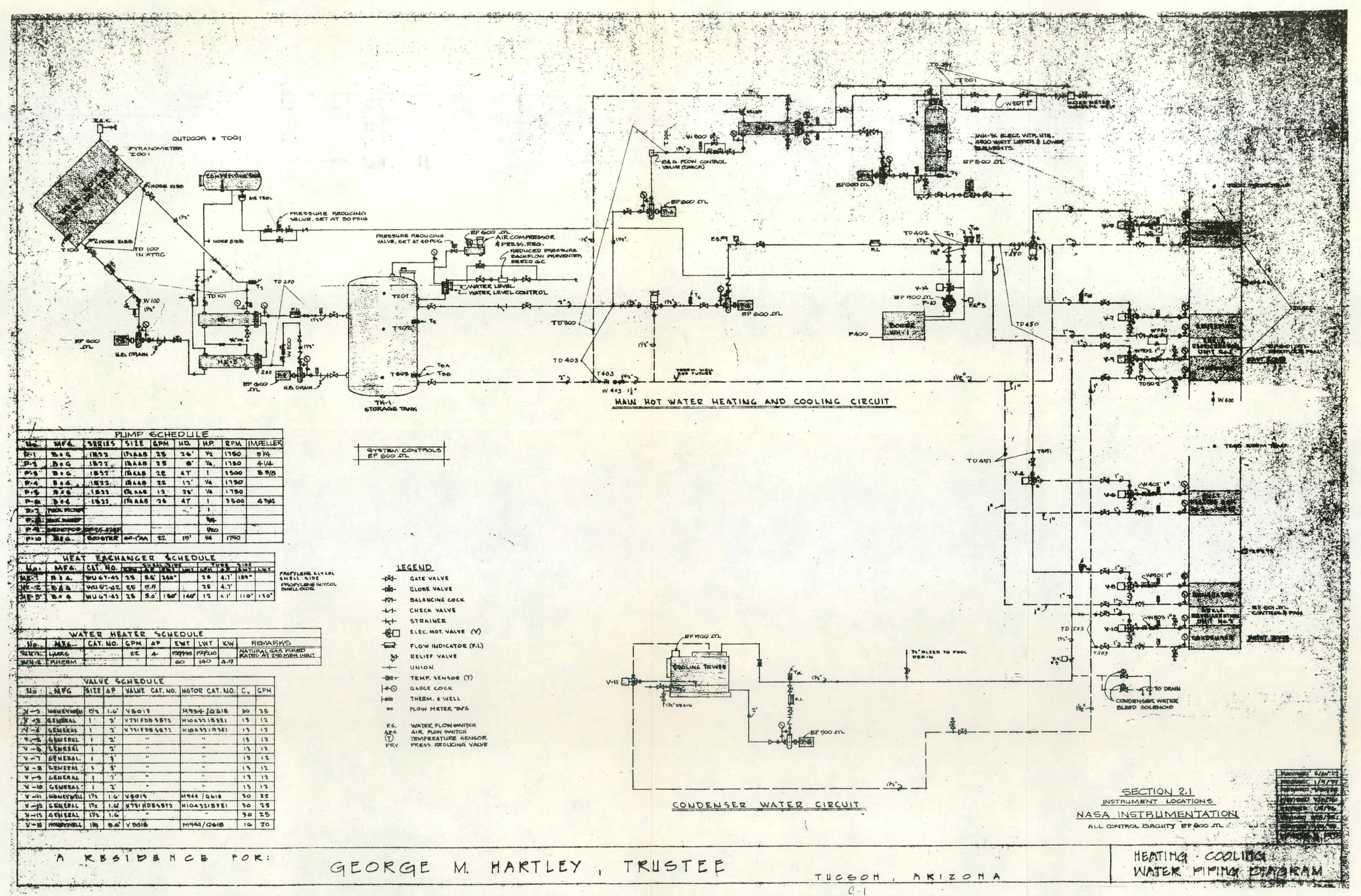


APPENDIX D 


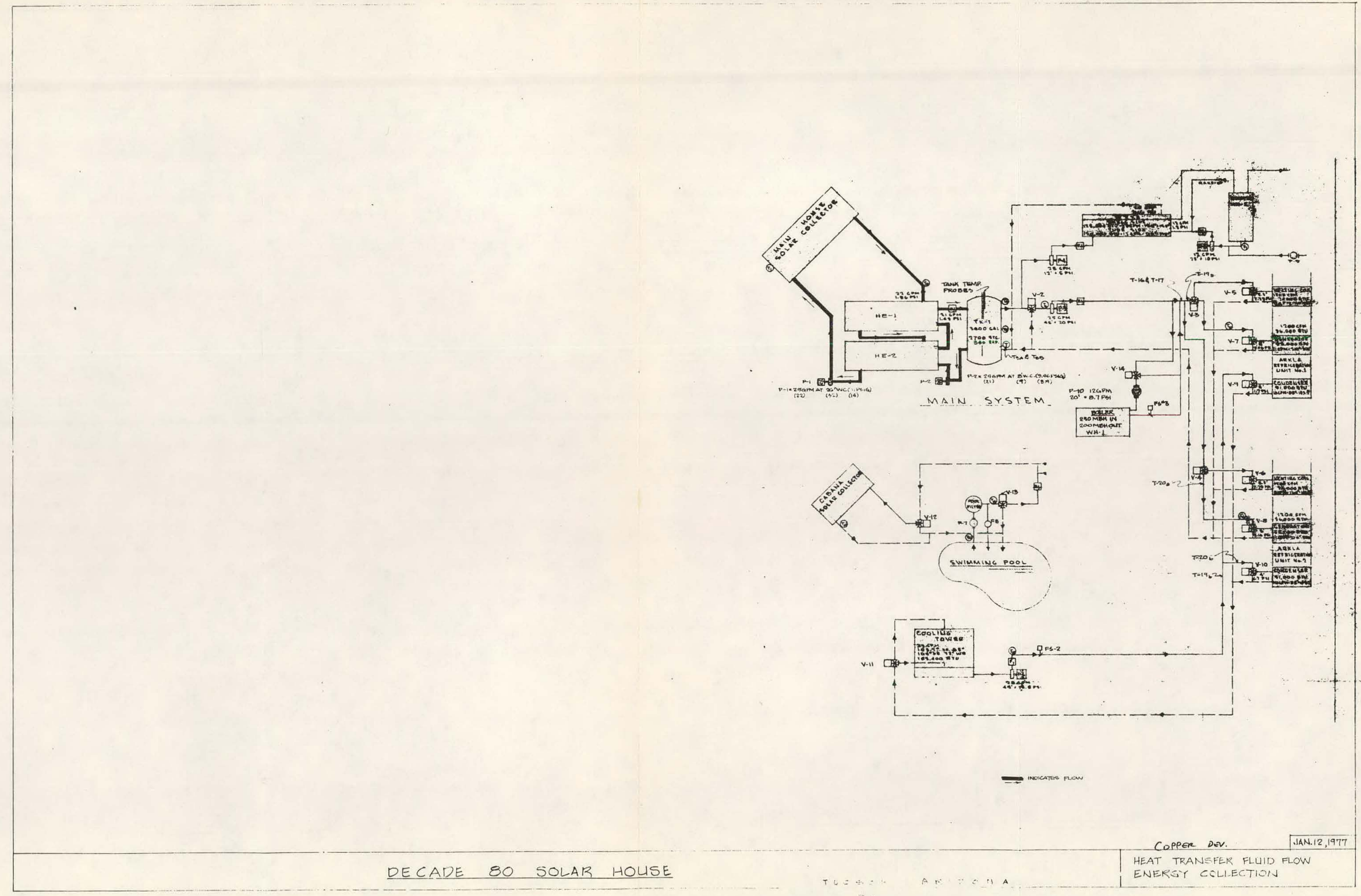




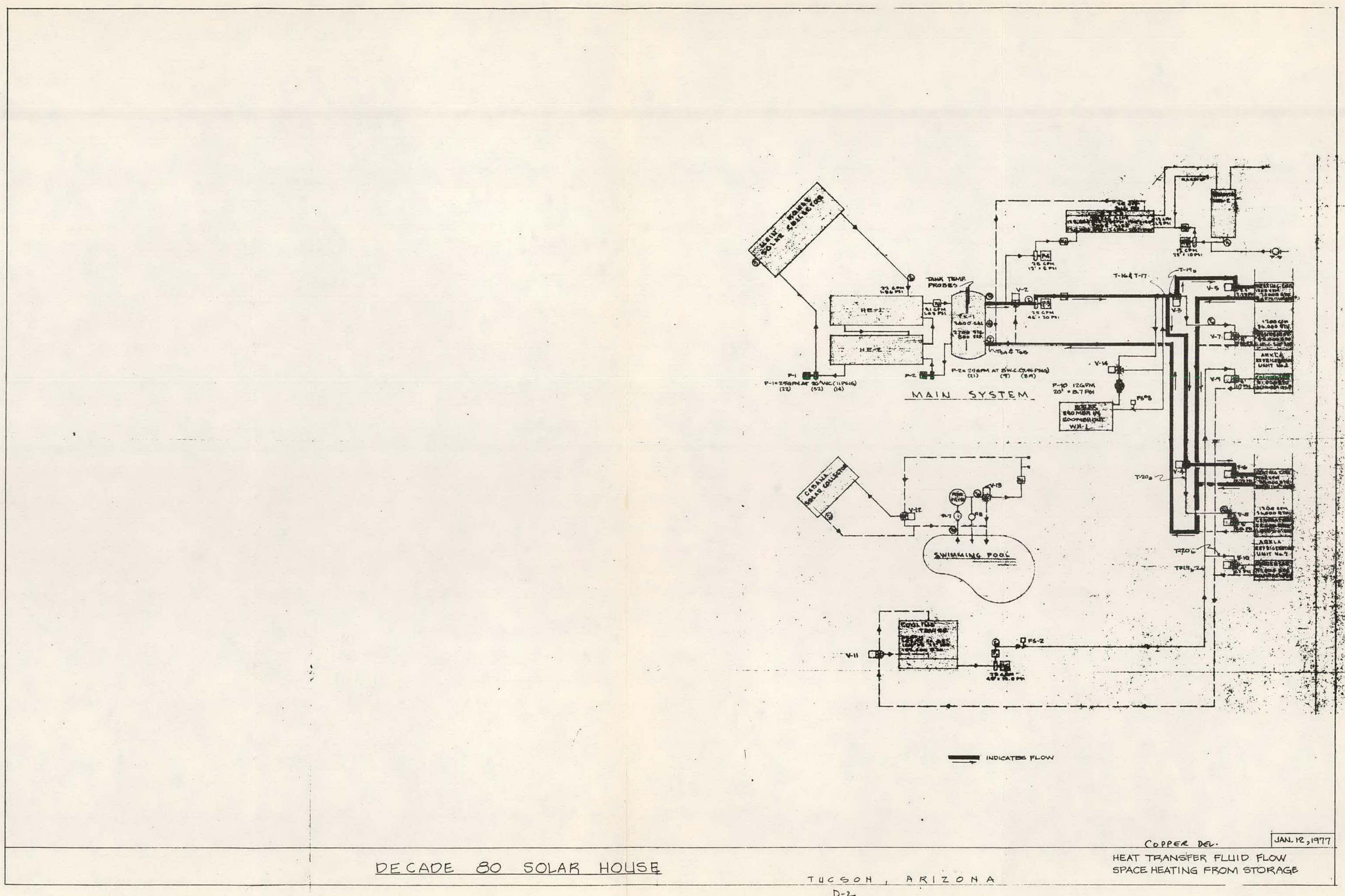




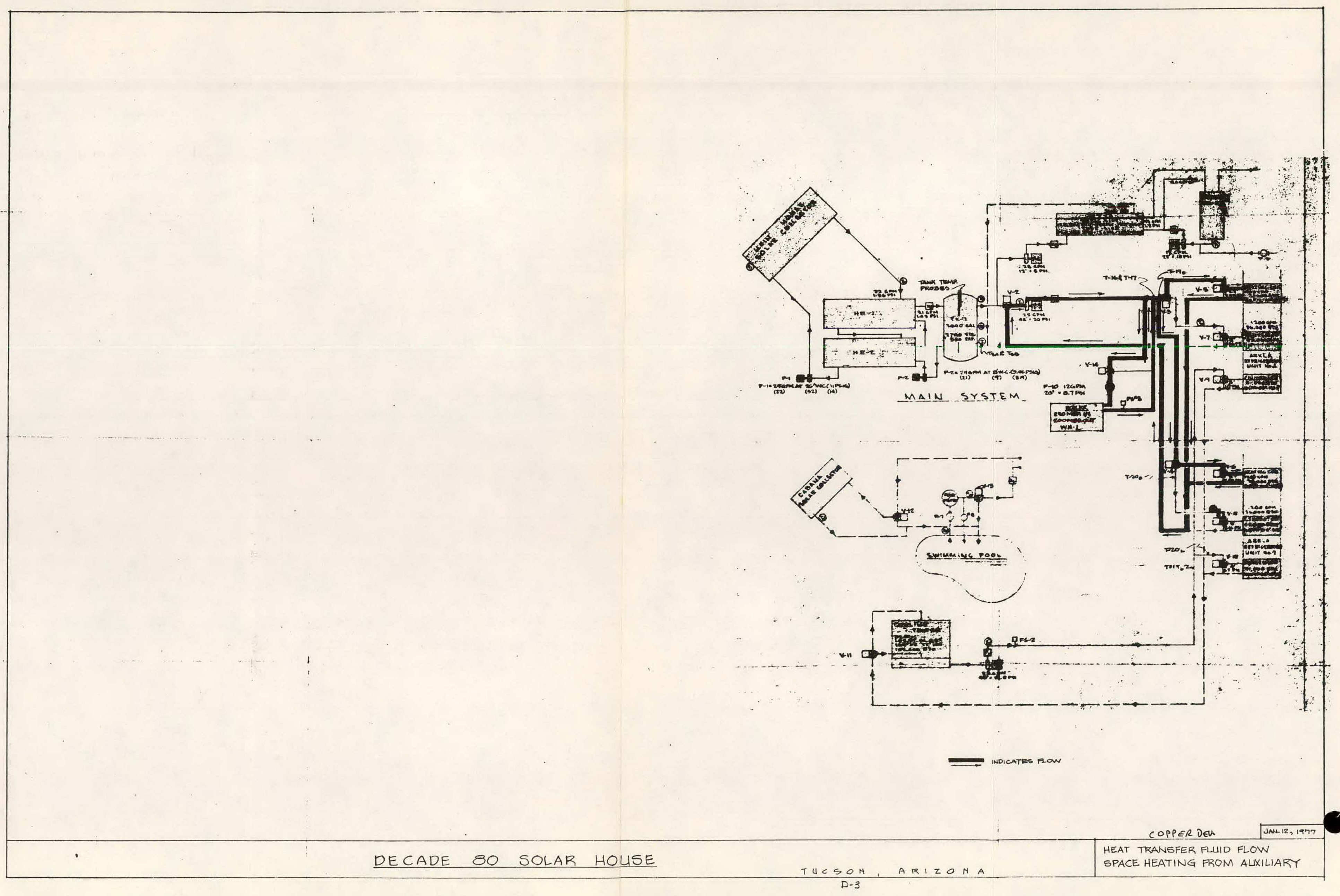




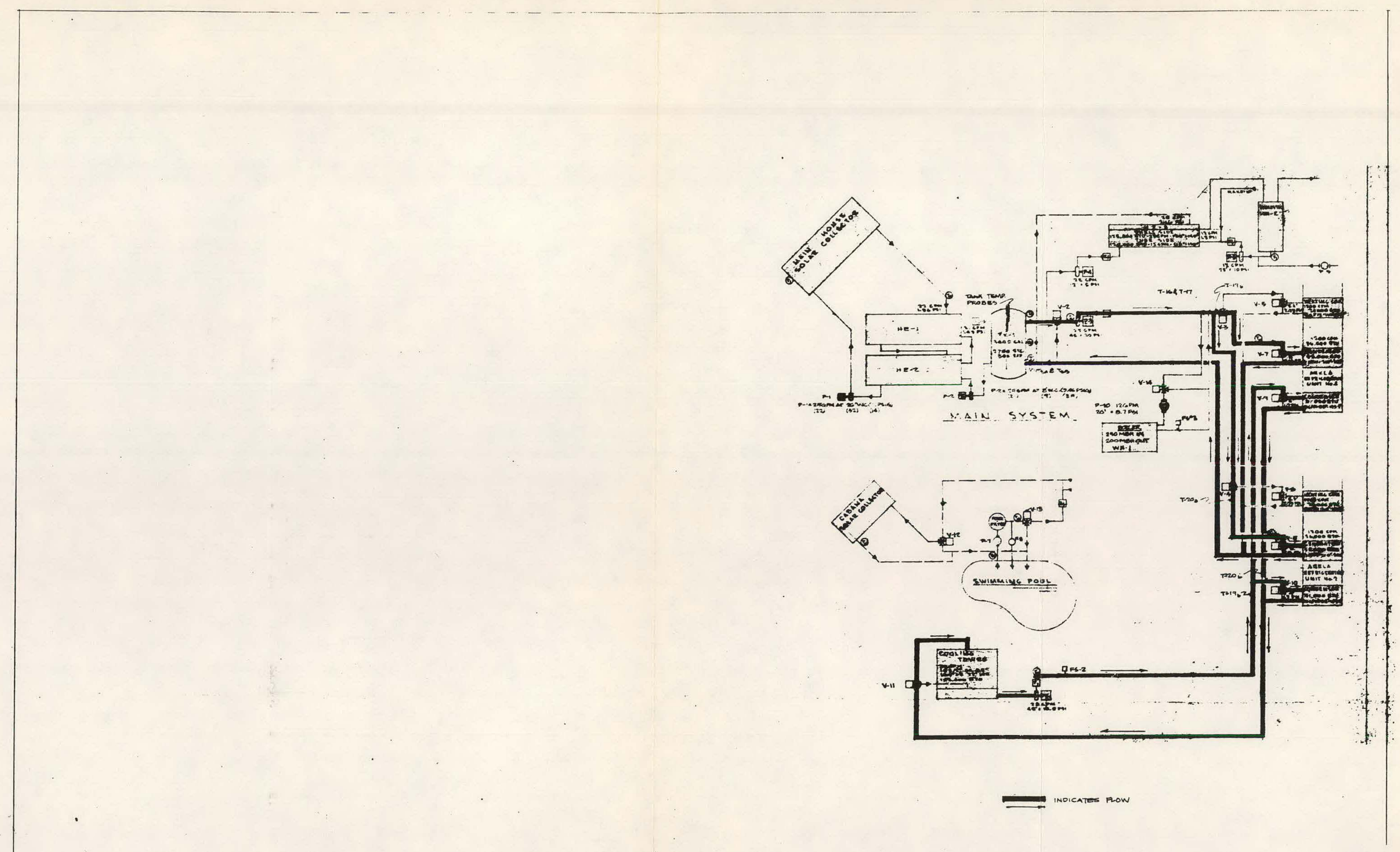




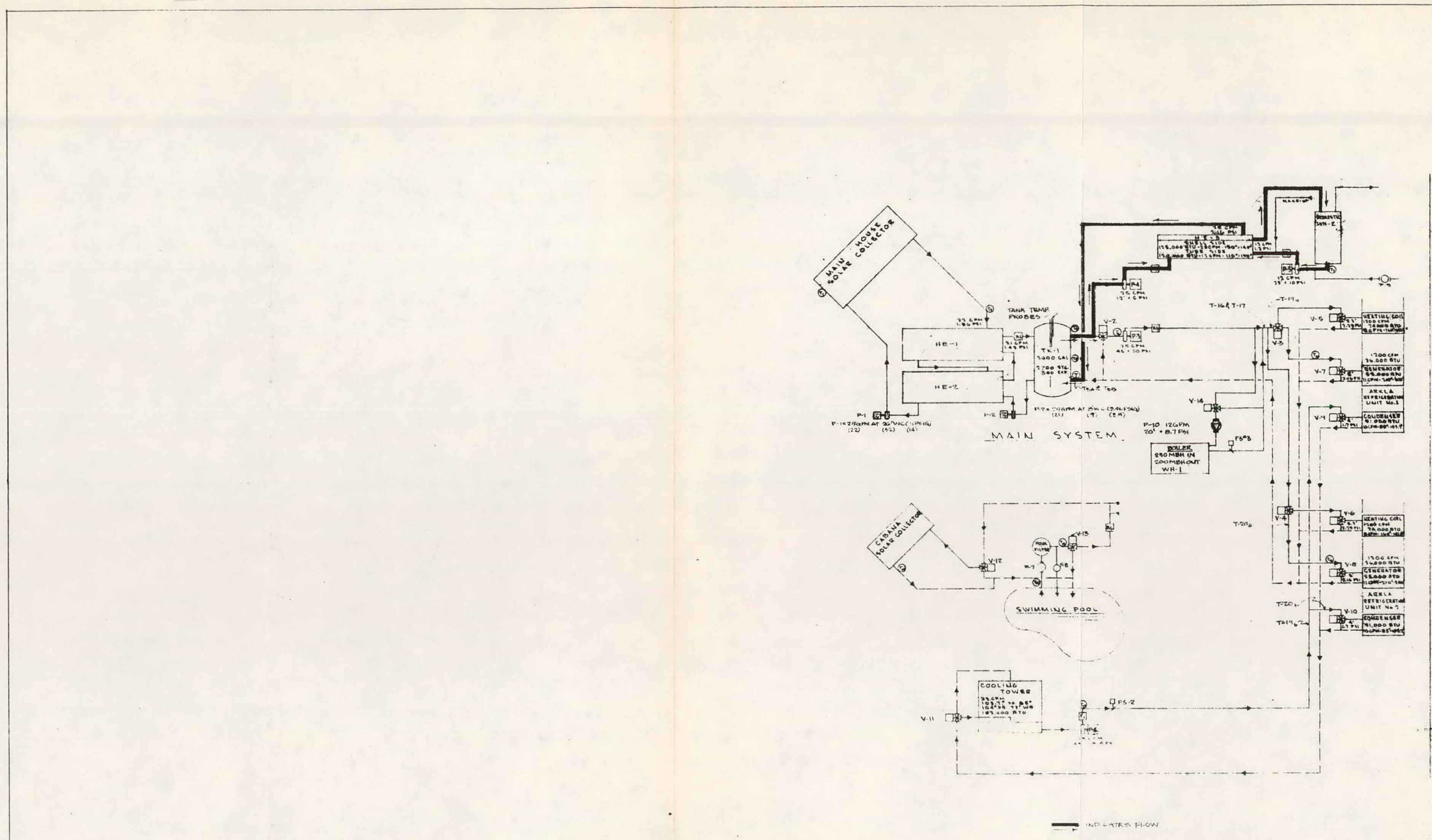

מU.S. GOVERNMENT PRINTING OFFICE 1978-640-081/263 REGION NO. 4 


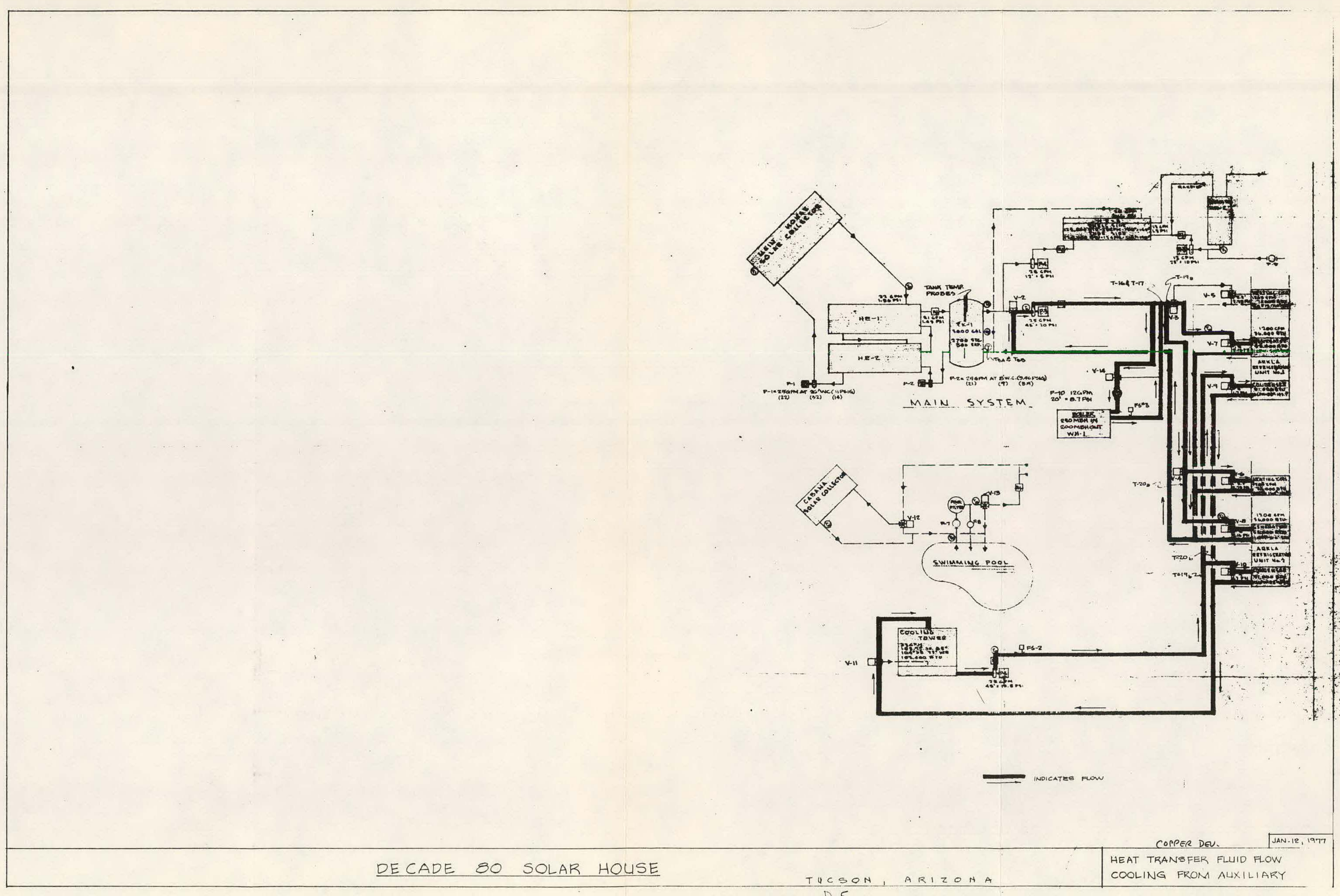

